\title{
STRESS-AND-STRAIN RECONSTRUCTION FOR THE EASTERN SEGMENT OF THE BALTIC SHIELD
}

\author{
L. A. $\operatorname{Sim}^{1}$, D. V. Zhirov², A. V. Marinin ${ }^{1}$
}

${ }^{1}$ Schmidt Institute of Physics of the Earth RAS, 123995, Moscow, Bol'shaya Gruzinskaya str., 10-1, Russia

${ }^{2}$ Geological Institute of the Kola Science Centre RAS, 184209, Apatity, Fersman str., 14, Russia

\begin{abstract}
The publication presents stress determinations from geological and kinematical indicators of tectonic stress fields, varying in ranks, for the Kola Peninsula. The objective is to determine possible mechanisms of formation of recent structures in the eastern segment of the Baltic shield and to forecast seismogenic and technogenic hazard of fracturing.

The study is focused on the Kovdor and Khibin Paleozoic alkaline-ultrabasic blocks. Tectonic stresses are reconstructed by M.V. Gzovsky's method [1954; 1975] based on identification of conjugated shear systems. Neotectonic stresses are studied by the kinematic method [Gushchenko, 1979] on the basis of measurements of tectonic displacment vectors from slickensides (Figure 2). Local stress data processed by the method for determination of general stress fields provide for reconstruction of main normal stresses which are arbitrarily considered as regional stresses [Sim, 1980; 2000]. This study uses the method of band-pattern distribution of fracturing in fault zones [Danilovich, 1961] which determines the main displacement line on the fault plane.

The study of the Zhelezny mining site (Kovdor block, Figures 3 and 4) revealed that elements of fractures of two different ages (centroclinal fractures of the prototectonic genesis and fractures of later tectonic activation) are spatially overlapping due to rock collapse and lacking stability of benches. Numerous inversions and changes of kinematics of relative displacements were reviewed. It was observed that the south-eastern wall of the quarry collapsed due to local extension (Fig. 6B and Photos 1 and 2), and a large fault, i.e. a prototectonic fracture, was dipping towards the quarry. Based on the analyses of local stresses at various points of the quarry (Table 1), two 'regional' stress fields can be revealed (Figures 7 and 8 ). The first paleostess field was associated with reverse faults of the WNW sub-horizontal axis of compression and the steeply dipping axis of extension. The second field was related to shear faults; its axis of compression maintained the WNW orientation, while the extension axis was reoriented, and the axis of extension attained sub-meridional position and a less steep dip. The second field is younger as suggested by traces of two displacements identified on several planes, the youngest of which are shears.
\end{abstract}

From the analysis of measurements taken at 273 planes with striations, it is evident that striations are distributed in a band-shape pattern. The band of fractures is coincident with the plane of the transition axis of the young 'regional field (Figure 9); main maximums of density of the planes with striations are symmetrically scattered in a fan-like pattern from the axis of compression and extension of this field. Generally, the striations reflect traces of younger displacements, and their consistency with the axes of the young field supports our conclusions on age relationships between the two 'regional' fields. Four major stages of deformation of the Kovdor block under study are distinguished by analyses of the tectonic stresses (Figure 10).

Within the limits of the Khibin block, 14 local states of stresses are reconstructed for three mining sites (Table 2, Figure 11). At the Central mining site, re-indexation of local axis of compression and extension in the fault wings give evidence of the fault activity during the neotectonic stage (Figure 13). The 'regional' stress field of the Khibin block is associated with a reserve fault with low-angle NNW orientation of the axis of compression (Figure 14). The tectonophysical studies conducted at the mining sites of the Kola Peninsula give grounds to conclude that activity of faults, which positions are different at the mining sites, is variable, depending on orientations of the faults against the youngest 'regional' main stress. From sets of indicators, a relative age of the revealed 'regional' fields of stresses is accepted as neotectonic and recent.

For the segments of the Kovdor block under study, four phases of deformation are distinguished, including two early phases revealed by structural indicators, and two last phases revealed from orientations of the axes of the main stresses in the reconstructed 'regional' fields. The reverse field of stresses of Deformation Phase 3 (which is a more ancient 'regional' field according to reconstructed tectonic stresses) at the Kovdor block and the reverse-fault field at the mining sites of the Khibin block may reflect a phase of brittle deformation of the rocks after the blocks were exposed to the day surface. Since then the deformation mechanisms might have been determined by two factors which controlled sub-horizontal compression: residual gravity stresses in considerably eroded magmatic bodies as 'recollections' of being subject to constraint environment at depth [Rebetsky, 2008], and the impact of rifting in the Northern Atlantics. The fact that the neotectonic 'regional' stress field of the Kovdor block is fully similar to that of the Central Karelia (Figure 1) give grounds to conclude that the mechanism of deformation of the block under study might have been controlled by both factors. The Khibin block has a lopolithic shape which 
gradually converts into a central-type conic structure with depth. It should thus be squeezed upward by the impact of horizontal compression of any genesis, as evidenced by the sub-vertical extension axis of the general field of the Khibin area and the recent topography as the highest mountains of the Kola Peninsula are located in the block under study.

Key words: Kola Peninsula, tectonophysics, fault tectonics.

Recommended by V.A. San’kov 29 August 2011.

Citation: Sim L.A., Zhirov D.V., Marinin A.V. Stress-and-strain reconstruction for the eastern segment of the Baltic shield // Geodynamics \& Tectonophysics. 2011. V. 2. № 3. P. 219-243. doi:10.5800/GT-2011-2-3-0044.

\title{
РЕКОНСТРУКЦИЯ НАПРЯЖЕННО-ДЕФОРМИРОВАННОГО СОСТОЯНИЯ ВОСТОЧНОЙ ЧАСТИ БАЛТИЙСКОГО ЩИТА
}

\author{
Л. А. Сим ${ }^{1}$, Д. В. Жиров ${ }^{2}$, А. В. Маринин ${ }^{1}$ \\ ${ }^{1}$ Институт физики Земли им. О.Ю. Шмидта РАН, 123995, Москва, ул. Большая Грузинская, д. 10, стр. 1, \\ Россия \\ ${ }^{2}$ Геологический институт Кольского научного центра РАН, 184209, Апатиты, ул. Ферсмана, д. 14, \\ Россия
}

Аннотация: Целью исследований являлась реконструкция по геолого-кинематическим индикаторам разноранговых полей тектонических напряжений на Кольском полуострове для определения возможных механизмов формирования новейших структур восточной части Балтийского щита, а также прогноза сейсмогенной и техногенной опасности разрывных нарушений.

Основные исследования проведены в пределах Ковдорского и Хибинского палеозойских щелочно-ультраосновных массивов. Для реконструкции тектонических напряжений в ограниченном объеме использовался метод выделения сопряженных сколовых систем трещин, разработанный М.В. Гзовским [1954, 1975]. Основным методом изучения неотектонических напряжений был кинематический метод О.И. Гущенко [1979], фактическим материалом для которого служили замеры векторов тектонических перемещений на зеркалах скольжения (рис. 2). По данным о локальных стресс-состояниях методом нахождения общих полей напряжений восстанавливаются главные нормальные напряжения условно регионального уровня [Сим, 1980, 2000]. В работе использовался метод поясного распределения трещиноватости в зонах разломов, предложенный В.Н. Даниловичем [1961], который позволяет определять линию главного перемещения по плоскости разлома.

На руднике «Железный» (Ковдорский массив, рис. 3, 4) установлено, что ряд обрушений и нарушений устойчивости уступов вызывает пространственное наложение и совмещение разрывных элементов двух различных этапов образования (центриклинальных трещин прототектонического генезиса и разрывных нарушений более поздней тектонической активизации), а также многочисленные инверсии и изменения характера кинематики относительных смещений. Так, обрушение юго-восточной стенки карьера обусловлено наличием обстановки локального растяжения (рис. 6), а также крупного разрывного нарушения - прототектонической трещины с падением в сторону карьера. В результате анализа локальных стресс-состояний, определенных в разных точках карьера (табл. 1), мы предполагаем наличие двух «региональных» полей напряжений (рис. 7, 8). Первое действовавшее здесь поле палеонапряжений взбросовое с 3СЗ ориентацией субгоризонтальной оси сжатия и крутой осью растяжения. Второе поле сдвигового геологического типа характеризуется осью сжатия, сохранившей свою ЗСЗ ориентировку, а также переиндексацией осей растяжения и промежуточной, при которой ось растяжения стала субмеридиональной и пологой. Возраст 2-го поля напряжений принимается более молодым по следам двух перемещений на отдельных плоскостях, из которых более молодые - сдвиговые.

Анализ плотности всех измеренных 273 плоскостей с бороздами скольжения показал их отчетливое поясное распределение. Пояс трещин совпадает с плоскостью действия промежуточной оси молодого «регионального» поля (рис. 9), а главные максимумы плотностей плоскостей с бороздами скольжения расходятся от оси сжатия и растяжения этого поля симметрично. Борозды скольжения обычно отражают следы наиболее молодых перемещений, такая согласованность их с осями молодого поля напряжений подтверждает справедливость определения возрастных взаимоотношений двух «региональных» полей. На основе изучения тектонических напряжений выделены четыре основные этапа деформирования изученной части Ковдорского массива (рис. 10).

В пределах Хибинского массива на трех рудниках восстановлено 14 локальных стресс-состояний (табл. 2, рис. 11). На руднике «Центральный» переиндексация локальных осей сжатия и растяжения в разных крыльях разлома свидетельствует о его активности на неотектоническом этапе (рис. 13). «Региональное» поле напряжений Хибинского массива характеризуется взбросовым типом с пологой ССЗ ориентировкой оси сжатия (рис. 14).

Проведенные на рудниках Кольского п-ова тектонофизические исследования позволили сделать несколько вы- 
водов. Степень активности разломов с разными элементами залегания на рудниках различна и зависит от их ориентации по отношению к новейшим «региональным» главным напряжениям. По комплексу признаков установлен относительный возраст выделенных «региональных» полей напряжений, который принят за неотектонический и современный.

На исследованной части Ковдорского массива выделены: два ранних этапа деформирования - по структурным признакам, два последних - по ориентации осей главных напряжений восстановленных «региональных» полей Взбросовое поле напряжений 3-го этапа деформирования (более древнее «региональное» по реконструкции тектонических напряжений) на Ковдорском массиве и взбросовое поле на рудниках Хибинского массива могут отражать, предположительно, этап хрупкого деформирования массива пород непосредственно после выведения массивов на дневную поверхность. С этого времени механизм деформирования мог определяться двумя факторами, обусловливающими субгоризонтальное сжатие: остаточными гравитационными напряжениями, сохранившимися в значительно эродированных магматических телах как «память» о пребывании в стесненных условиях на глубине [Rebetsky, 2008], и влиянием рифтогенеза в Северной Атлантике. Полная аналогия неотектонического «регионального» поля напряжений Ковдора с таковым в Центральной Карелии (рис. 1) позволяет считать, что механизм деформирования указанного массива могут определять оба источника. Хибинский массив, имеющий лополитообразную форму, переходящую ниже в коническую структуру центрального типа, под воздействием горизонтального сжатия любого генезиса должен выдавливаться вверх, что фиксируется субвертикальной осью растяжения общего поля Хибин и подтверждается современным рельефом - наиболее высокие вершины Кольского п-ова находятся именно на этом массиве.

Ключевые слова: Кольский полуостров, тектонофизика, разломная тектоника.

\section{1. ВВЕДЕНИЕ}

Изучение напряженного состояния в массивах горных пород по геологическим индикаторам имеет свои специфические особенности. Они связаны с неоднородной информативностью геологических данных, используемых для реконструкции тектонических напряжений, с определением их возраста, с проблемами ранжирования и установления взаимосвязи полей напряжений и разломов разных рангов, с сопоставимостью полученных результатов с данными инструментальных наблюдений и т.д. В то же время тектонофизические исследования указанного типа имеют важное теоретическое и практическое значение. В предлагаемой работе обсуждаются некоторые аспекты тектонофизических исследований, проведенных по геологическим данным о напряжениях. Работы были выполнены в 2009 и 2010 гг. на Ковдорском и Хибинском щелочно-ультрабазитовых массивах и в отдельных точках Мурманского блока Кольского п-ова. Они возобновляют и продолжают тектонофизические исследования, выполнявшиеся на Балтийском щите в 70-80 годах прошлого века.

Целью исследований являлась реконструкция тектонических напряжений на рудных объектах Кольского п-ова для прогноза степени опасности разрывных нарушений и исследование возможных механизмов формирования новейших структур восточной части Балтийского щита.

\section{2. КРАТКАЯ ИСТОРИЯ ГЕОЛОГИЧЕСКОГО РАЗВИТИЯ РАЙОНА РАБОТ}

Район исследований расположен в пределах северовосточной части Балтийского (Фенноскандинавского) докембрийского щита. Главные структурно-вещественные комплексы и блоковая (доменная - террейновая) структура Кольского региона сформировались преимущественно в период неоархея - раннего протерозоя. Первые «микроконтиненты» - сиалические ядра - начали формироваться, вероятно, ранее 3 млрд лет. Рост коры и ее эволюция осуществлялись за счет аккреции и орогении. Все составные части Кольского кратона имеют отличительные индивидуальные черты архейской истории развития, что свидетельствует о значительной пространственной разобщенности этих блоков в рассматриваемый период. В это же время активно развивались вулканогенно-осадочные пояса, глубокометаморфизованные зеленокаменные и парагнейсовые комплексы которых сегодня представлены в различной степени фрагментированными и микшированными реликтами архейских зеленокаменных поясов. Породы нестратифицированного основания, как первично осадочного, так и первично плутонического генезиса, неоднократно испытали в неоархее (2.8-2.9 млрд лет) метаморфизм высоких ступеней с различными по характеру и интенсивности деформациями и дислокациями [Строение..., 2006]. В масштабах всего Кольского кратона в архее преобладали тектонические движения блоков с преимущественной горизонтальной составляющей и в меньшей мере - с вертикальной.

В период последующей коллизии (2.7-2.5 млрд. лет назад) позднеархейские комплексы были дислоцированы, метаморфизованы в условиях от амфиболитовой до гранулитовой фации, а регион был преобразован в архейский интраконтинентальный Кольско-Беломорский коллизион [Геология..., 2002]. Тектоника архея рассматривается как тектоника малых и тонких плит, подстилаемых мигматитовым слоем средней коры и анортозит-эндербит-гранулитовой нижней корой. По 
Ф.П. Митрофанову, масштабным горизонтальным и субдукционным перемещениям на этой стадии препятствовали гетерофазные условия их взаимодействия [Митрофанов и др., 1997].

В раннепротерозойский период (2.5-1.7 млрд лет назад) протоплатформа имела значительные размеры и явилась «ловушкой» для поднимающегося мантийного плюма, над которым образовалось сводовое поднятие коры с возникновением интракратонных рифтовых зон (Печенга, Имандра-Варзуга и др.) и интенсивным проявлением базит-гипербазитового магматизма. Тектонические процессы сумийского рифтинга привели к образованию авлакогенов, а ятулийского и свекофенского - палеорифтов. На поздних этапах преобладали значительные тангенциальные движения, с которыми связано формирование многочисленных складчатых и надвиговых структур. Оно происходило зонально с различным распределением интрузий базитов и гипербазитов в разных зонах [Геология..., 2002].

В позднем протерозое (1.65-0.65 млрд лет назад) в режиме платформы на юго-востоке и востоке региона сформировались континентальные отложения, а на севере - образования шельфа и континентального склона. С этого времени в регионе преобладали блоковые радиальные тектонические движения. При общей тенденции к воздыманию происходила неравномерная эрозия и пенепленизация региона [Геология..., 2002].

Палеозойский этап характеризуется большим разнообразием продуктов магматизма. Складчато-надвиговые процессы на северо-западе щита вызвали тектоническую и эндогенную активизацию в консолидированной коре региона. В это время сформировались новые и обновились старые разломы с неоднородными движениями по ним, а также был проявлен активный щелочно-ультраосновной магматизм: произошло внедрение Ковдорского массива (378.5-372.2 млн лет), Хибинского и Ловозерского плутонов (371-362 млн лет) и других массивов. Наиболее древними палеозойскими магматическими образованиями Кольского пова являются кимберлиты и кимберлитоподобные породы трубок взрыва Терского побережья (465-376 млн лет).

В палеозое сформировались вулканогенные, вулканогенно-осадочные и осадочные породы, сохранившиеся в виде останцов девонских пород на Хибинском и Ловозерском массивах и каменноугольных - в Контозерской кальдере.

К мезозойским образованиям относится дайка нефелинитов Турьего мыса - 175-150 млн лет [Рухлов и др., 1999; Геология..., 2002].

Спецификой неотектонического этапа Балтийского щита и Кольского региона как его составной части является практическое отсутствие новейших отложений и совмещение тектонических движений с гляциоизостатическими. Начало новейшего этапа относится к концу олигоцена, когда море ушло с северо-запада Русской плиты [Бабак, Николаев, 1983; Карта новей- шей тектоники...1985; Garetsky et al., 1999]. Амплитуды новейших движений на плите рассчитывались по деформациям исходной поверхности - кровли нижнего олигоцена (рюпельские слои, харьковская свита), а в пределах щита - по деформациям поверхностей выравнивания.

В связи с отсутствием палеоген-неогеновых отложений на щите кайнозойская тектоника региона лучше изучена на позднеплейстоценовом-голоценовом этапе. Некоторая определенность в вопросе о начале неотектонического этапа была получена при оценке возможной величины эрозионного сноса с Фенноскандии в мезозое - кайнозое. Для такой оценки по литологопалеогеографическим картам мира [Ронов и др., 1989] с определенными допущениями были проанализированы мощности осадков этого времени в бассейнах Баренцева, Норвежского и Северного морей, в осредненном виде соответствующие величине эрозионного сноса. Мощности осадков позволили оценить скорость воздымания щита: в эоцене она равна 0.022 мм/год, в олигоцене -0.053 мм/год, в миоцене -0.009 мм/год и в плиоцене -0.146 мм/год [Сим, 2010]. Согласно полученным данным подтверждено общепринятое начало неотектонического этапа в олигоцене, при этом в плиоцене отмечается ярко выраженный импульс активности внутри новейшего этапа, даже если в расчете скоростей подъема щита не учтены некоторые специфические особенности осадконакопления этого времени.

В позднем плейстоцене - голоцене для разных участков Кольского региона характерны региональные и локальные движения с неоднородной вертикальной амплитудой [Кошечкин, 1979].

На последних стадиях развития региона значительная роль принадлежит оледенениям. Амплитуда опускания из-за ледникового покрова на Кольском п-ове оценивается в первые десятки метров. Суммарная амплитуда перемещений за олигоцен - плиоцен достигала 1000 м, а в голоцене - 150 м и более. Постледниковое расчленение рельефа обусловлено «клавишным» характером дифференцированных вертикальных блоковых движений как докембрийских, так и палеозойских структур и массивов. Процессы поднятия продолжаются и в настоящее время. Линейные зоны границы крупных структур региона - характеризуются повышенной сейсмичностью [Геология..., 2002].

$\mathrm{K}$ расположенной в восточной части Балтийского щита флексуре Полканова (имеющей северо-восточное простирание) ортогонально расположены шовные зоны северо-западного простирания, к которым относятся и Ладожская, и Кандалакшская горсто-грабеновые системы.

Шовные зоны сопровождаются ярко выраженными осевыми линиями зон сосдвиговых движений второго порядка, указывающих на левосдвиговые раннелопийские перемещения.

В новейший этап по большинству из этих шовных 


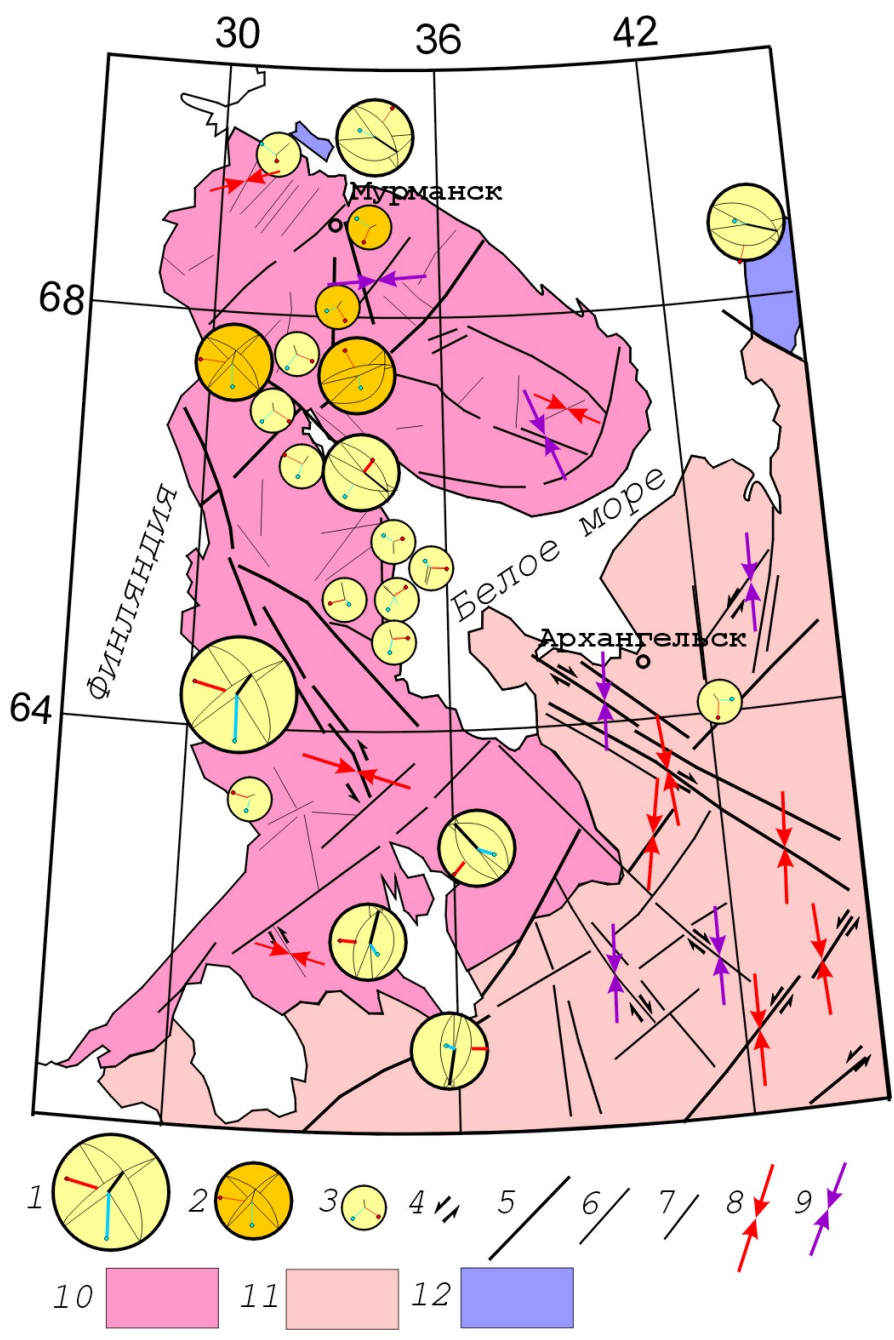

Рис. 1. Схема изученности тектонических напряжений восточной части Балтийского щита по геологическим индикаторам (по Л.А. Сим [2000], с изменениями). 1-3 - стереограммы неотектонических напряжений, реконструированных кинематическим методом О.И. Гущенко [1973, 1979]: 1 - I, 2 - II, 3 - III ранга; показаны плоскости действия максимальных касательных напряжений и оси: красный цвет - максимальные, синий - минимальные, черный промежуточные главные нормальные напряжения. Стереограммы темно-желтого цвета - реконструкции 2009-2010 гг. (сетка Вульфа, верхняя полусфера); 4 - сдвиги; 5-7 - разломы: 5 - I, 6 - II, 7 III ранга; 8-9 - оси максимальных сжимающих напряжений в горизонтальной плоскости, восстановленные структурно-геоморфологическим методом [Сuм, 1991]: 8 - I, 9 - II ранга; 10-12 - геологические структуры: 10 - Фенноскандинавский (Балтийский) щит, 11 - Русская плита, 12 - байкалиды Тимана.

Fig. 1. Schematic map of the Eastern segment of the Baltic shield covered by studies of geological indicators (modified from [Сим, 2000]). 1-3 - stereograms of neotectonic stresses determined by O.I. Gushchenko's method [Гущенко, 1973, 1979]: 1 - Rank I, 2 Rank II, 3 - Rank III; planes of maximum tangential stresses and axes: red - maximum; blue - minimum; black - transitional main normal stresses. Dark-yellow stereograms show stresses reconstructed for 2009-2010 (The Wulff net, upper hemisphere); 4 - strike-slip faults; 5-7 - faults: 5 - Rank I, 6 - Rank II, 7 - Rank III; 8-9 - axes of maximum compression stresses in the horizontal plane that are restored by the structural-geomorphological method [CuM, 1991]: 8 - Rank I, 9 Rank II; 10-12 - geological structures: 10 - Fennoscandian (Baltic) Shield, 11 - Russian plate, 12 - baikalids of Timan. зон, дешифрирующихся как крупные разломы, с помощью тектонофизических исследований также восстановлены левовосдвиговые компоненты перемещений, которые либо «реанимировали» направление лопийских смещений, либо развиваются унаследованно [Сим и др., 2009].

\section{3. ИЗУЧЕННОСТЬ ТЕКТОНИЧЕСКИХ НАПРЯЖЕНИЙ ВОСТОЧНОЙ ЧАСТИ БАЛТИЙСКОГО ЩИТА ПО ГЕОЛОГИЧЕСКИМ ИНДИКАТОРАМ}

С конца 70-х годов прошлого века преимущественно коллективами специалистов геологического факультета МГУ [Бабак и др., 1979, 1981; Кольская сверхглубокая, 1984; Сим и др., 1987, 1990; Сим, 1991, 1996; Николаев, 1992] в пределах восточной части Балтийского щита были инициированы по существу первые исследования тектонических напряжений по геологическим индикаторам. Наиболее детально охарактеризовано напряженное состояние Центральной Карелии в связи с изысканиями, проводившимися в 1987-1988 гг. при выборе площадки под строительство Карельской АЭС. Кинематическим методом, разработанным О.И. Гущенко [1973, 1979] по бороздам скольжения, измеренным в древних архей-протерозойских отложениях, была установлена значительная изменчивость локальных стресс-состояний на площади $100 \times 100 \mathrm{KM}$.

По осям напряжений локального уровня было восстановлено общее поле напряжений сдвигового типа с запад-северо-западной ориентировкой оси сжатия и меридиональной - растяжения. Острая проблема возраста восстановленных тектонических напряжений была решена путем комплексного геохимического профилирования на детальных участках, сложенных голоценовыми ледниковыми отложениями. По данным об ориентации региональных главных напряжений Центральной Карелии для опорных детальных участков, выделенных по дешифрированию, были спрогнозированы кинематические типы разломов. Геохимические исследования показали аномально высокие содержания радона и углекислого газа вблизи широтного разлома, нормального к оси растяжения, а также в секторах локального растяжения, образованного при пересечении спрогнозированных на основании восстановленных в древних породах тектонических напряжений разнонаправленных сдвигов. Таким образом, тектонические напряжения, реконструированные по бороздам скольжения, характеризуют и современное напряженное состояние, соответственно, возраст этих напряжений неотектонический и современный. Кроме результатов геохимических исследований неотектонический возраст восстановленных кинематических напряжений подтверждается новейшей структурой Кандалакшского грабена. По геологическим данным он образовался в конце мезозоя - кайнозое; ось растяже- 
ния II ранга, ориентированная нормально к оси грабена, соответствует механизму его формирования [Сим и др., 1990; Сим, 1996, 2000].

В конце XX в. проведено обобщение практически всех геологических данных по новейшему напряженному состоянию восточной части Балтийского щита (рис. 1). Основной вывод, последовавший из этого обобщения, заключался в том, что региональные тектонические напряжения указанного региона характеризуются сдвиговым типом с запад-северо-западной ориентацией оси сжатия и субмеридиональным растяжением, что хорошо коррелируется с данными инструментальных измерений современных напряжений и с данными по механизмам очагов землетрясений вдоль северо-западного побережья Фенноскандии [Zoback et al., 1989].

\section{4. МЕТОДИКА РАБОТ}

Основные принципы анализа полей напряжений, действующих в определенных объемах земной коры, были сформулированы М.В. Гзовским, впервые начавшим систематическое изучение современных и древних тектонических напряжений. Им предложен метод выделения сопряженных пар трещин [Гзовский, 1954, 1975], использовавшийся нами в единичных случаях для решения частных задач. Метод основан на положениях теории прочности Кулона, согласно которой разрушение материала и образование разрыва связываются с плоскостями действия максимальных касательных напряжений. Положение сколовых трещин отличается от указанных плоскостей на угол скалывания $\alpha$. Таким образом, сколовые трещины расположены от оси сжатия $\sigma_{3}$ под углом $45^{\circ}-\alpha$ (т.е. биссектриса острого угла между сопряженной парой сколовых трещин есть ось сжатия $\sigma_{3}$, а тупого угла, соответственно, ось растяжения $\left.\sigma_{1}\right)$. Промежуточная ось $\sigma_{2}$ совпадает с линией пересечения сопряженных сколов. Проверкой справедливости восстановленных по сопряженным сколам ориентировок осей главных нормальных напряжений служат разнонаправленные векторы перемещений на сопряженных трещинах (разрывах).

Наиболее широко в работах 2009-2010 гг. использовался кинематический метод О.И. Гущенко. В этом методе реконструкции направлений действия главных напряжений и типа напряженного состояния используется взаимосвязь всей совокупности касательных напряжений, действующих на различно ориентированных площадках в однородно-напряженных участках деформируемой среды, с направлениями действия главных нормальных напряжений [Гущенко, 1973, 1979; Гущенко, Сим, 1974]. Обоснование метода опирается на теорию дислокационного скольжения Батдорфа-Будянского и содержит три основные предпосылки: упруго-пластическое деформирование в задан- ном однородно-осном поле напряжений в геологической среде происходит как за счет смещений по вновь образующимся поверхностям трещин (разрывов), так и за счет перемещений по уже существующим ослабленным сечениям любого возраста и генезиса; каждое смещение вызывает возмущение поля напряжений только более мелкого масштабного уровня, а исходное поле напряжений остается неизменным; направление смещения вдоль всей поверхности сместителя совпадает с направлением касательного напряжения на этой поверхности и отвечает заданному полю напряжений. Важным условием применимости кинематического метода является положение о том, что «борозды скольжения являются следами последних... наиболее молодых сдвиговых тектонических подвижек, а следы более ранних смещений или стираются, или имеют худшую сохранность» [Гущенко, 1979, с. 9], что согласуется с данными, приводимыми почти во всех учебниках по структурной геологии.

Для характеристики взаимосвязи всей совокупности касательных напряжений на различно ориентированных площадках в однородно-напряженных участках деформируемой среды с направлениями действия главных нормальных напряжений были рассчитаны и построены стереограммы-номограммы распределения ориентировок касательных составляющих напряжений для различных типов тензоров напряжений (для коэффициента Лоде-Надаи $\mu \sigma= \pm 1$ и $\mu \sigma=0$ ) [Гущенко, 1979]. Согласно этим номограммам, векторы перемещений расходятся от оси сжатия и сходятся к оси растяжения, границей разнонаправленных векторов служат плоскости действия осей $\sigma_{1}$ и $\sigma_{3}$; при одноосном напряженном состоянии векторы совпадают с дугами больших кругов, расходящихся от оси сжатия $\sigma_{3}(\mu \sigma=1)$ или оси растяжения $\sigma_{1}(\mu \sigma=-1)$, а при трехосном напряженном состоянии они должны находиться в створе острого угла, образованного этими дугами (рис. 2).

Метод нахождения общего поля напряжений по данным о локальных стресс-состояниях и выделение рангов полей напряжений. Данные математического моделирования характера локальных полей напряжений в окрестностях разрыва при смещении по нему [Осокина, 1987, 1997] позволили обосновать принцип выделения общего поля напряжений, вызвавшего перемещение по указанному разрыву. Он сводится к следующему: если все оси $\sigma_{1}$ или $\sigma_{3}$ локальных напряжений являются одноранговыми и вызваны перемещением по разрыву более высокого (крупного) ранга, то они должны описываться конусами сжатия и растяжения с углом при вершине $90^{\circ}$. При этом в конусе сжатия не должно быть осей растяжения и, наоборот, в конусе растяжения не должно быть осей сжатия. Оси конусов взаимно перпендикулярны и являются осями сжатия и растяжения общего поля напряжений, а точки их касания - полюсами площадок действия максимальных касательных напряжений. Взаимно перпендикулярные локальные оси сжатия и растяжения в разных крыльях 

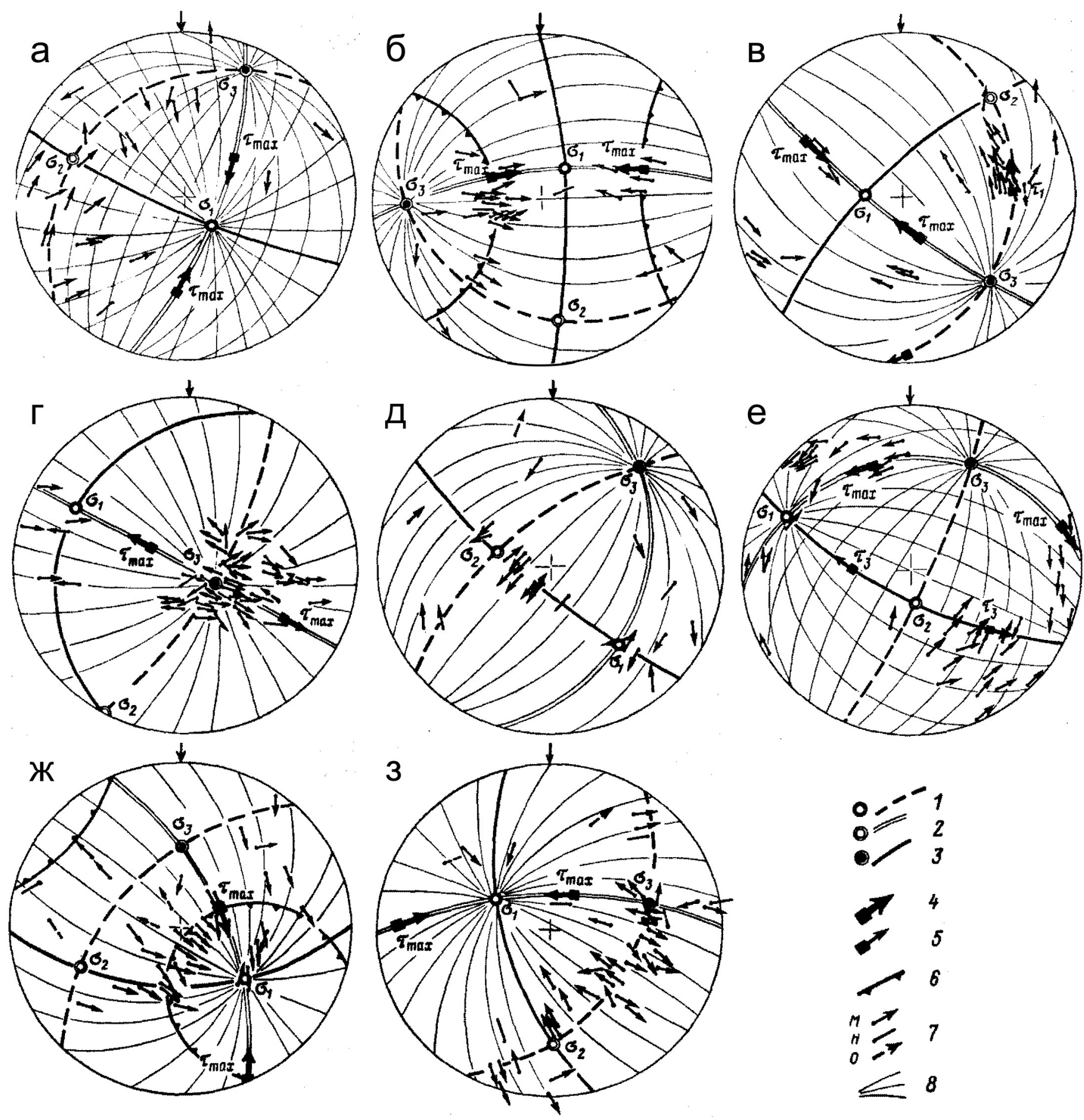

Рис. 2. Стереограммы локальных стресс-состояний Приполярного Урала с различными значениями коэффициента Лоде-Надаи. Сетка Вульфа, верхняя полусфера: $a, e-$ трехосное напряженное состояние; б-д - одноосное сжатие; ж, з - одноосное растяжение. 1-3 - оси главных нормальных напряжений и плоскости их действия: 1 - минимальных $\left(\sigma_{1}\right), 2$ - промежуточных $\left(\sigma_{2}\right)$ и 3 - максимальных сжимающих напряжений $\left(\sigma_{3}\right) ; 4-5$ - полюса плоскостей действия касательных напряжений: 4 - максимальных, 5 - прочих; 6 - границы конусов сжатия и растяжения; 7 - векторы перемещений на зеркалах скольжения: м, н - согласующиеся с найденными осями главных нормальных напряжений: $\boldsymbol{M}$ - с установленным, $\boldsymbol{\text { н }}$ - с неопределенным знаком смещения; $o$ - противоречащие найденным осям напряжений; 8 - дуги больших кругов, расходящиеся от осей сжатия и растяжения.

Fig. 2. Stereograms of local states of stresses of the Polar Urals with various values of the Lode-Nadai factor. The Wulff net, upper hemisphere: $a$, $e$ - three-axes state of stresses; $\sigma-\partial$ - single-axis compression; $ж$, 3 - single-axis extension. $1-3$ - axes of main normal stresses and planes: 1 - minimum $\left(\sigma_{1}\right), 2$ - transitional $\left(\sigma_{2}\right)$ and 3 - maximum compression stresses $\left(\sigma_{3}\right) ; 4-5$ - poles of tangential stress planes: 4 - maximum, 5 - other; 6 boundaries of compression and extension cones; 7 - displacement vectors on slickensides: $\boldsymbol{M}, \boldsymbol{H}$ - consistent with the determined axes of main normal stresses: $\boldsymbol{M}$ - with established displacement sign, $\boldsymbol{H}$ - with non-determined displacement sign; $o$ - contradicting to the determined stress axes; 8 - arcs of large circles diverging from axes of compression and extension. 
разрывов на их концах попадают в область между конусами сжатия и растяжения [Cuм, 1980, 2000].

Определение общего поля напряжений по данным о локальных стресс-состояниях по технологии совпадает с нахождением региональных тектонических напряжений по сейсмологическим данным, предложенным в кинематическом методе [Гущенко, 1979].

Метод поясов трещин В.Н. Даниловича. Метод, предложенный В.Н. Даниловичем [1961], основан на анализе трещиноватости вблизи крупных разломов. Большое число натурных данных показало, что вблизи разломов сколового типа более мелкие трещины образуют пояс трещиноватости. Кроме этого еще один локальный максимум плотности трещиноватости часто наблюдается вблизи полюса пояса трещиноватости.

Этот метод, прежде всего, был ориентирован на определение направления движения по крупным разломам с известным залеганием плоскости сместителя. В дальнейшем С.И. Шерман [1966] развил метод В.Н. Даниловича для определения элементов залегания плоскости разлома. Сопоставление экспериментальных и натурных данных позволило использовать этот метод для реконструкции главных осей тензора напряжений. Было установлено, что ось пояса совпадает с осью промежуточного главного напряжения, а анализ ориентации трещин отрыва и скола позволяет определить ориентацию двух других главных осей.

\section{5. РЕЗУЛЬТАТЫ РЕКОНСТРУКЦИИ ТЕКТОНИЧЕСКИХ НАПРЯЖЕНИЙ В ВОСТОЧНОЙ ЧАСТИ БАЛТИЙСКОГО щиТА}

В 2009 и 2010 годах на Ковдорском и Хибинском щелочно-ультрабазитовых массивах Кольского полуострова и в отдельных точках севернее них были возобновлены тектонофизические исследования, проводившиеся на Балтийском щите в 70-80 годах прошлого века. Основные исследования проводились на карьерах рудников «Железный» (Ковдорский массив), «Центральный», «Олений Ручей» и «Коашва» (Хибинский массив)

Ковдорский массив. Ковдорский массив прорывает биотитовые гнейсы и гранитогнейсы кольско-беломорского комплекса архея, которые образуют крупную моноклинальную структуру с общим падением на северо-восток. С вмещающими породами массив имеет эруптивные контакты. Структура массива представлена сложным сочетанием цилиндрических, конических и неполнокольцевых форм, обусловленных последовательным внедрением различных по составу интрузий. Массив отличает очень разнообразный состав пород, отраженный на геологической карте (рис. 3). Помимо разного состава магматических пород значительная неоднородность минералогического состава пород обусловлена неоднократными метасоматическими процессами и длительным периодом выветривания, которому подвергся массив на различных этапах своего развития. По данным Rb-Sr-метода возраст оливинитов и пироксенитов массива (центр и северо-запад массива) колеблется в интервале 373-376 млн лет [Zeitsev, Bell, 1995]. Близко к нему находится определение возраста бадделеитов из фоскоритов и карбонатитов, полученный U-Rb методом [Геология рудных районов..., 2002].

Тектонофизические исследования были сосредоточены в пределах карьера рудника «Железный» (рис. 4).

На верхних и средних горизонтах карьера были произведены массовые замеры трещиноватости (около 2000 записей в карьере и более 1300 - по ориентированному керну), а в 23 точках наблюдений в разных бортах были измерены векторы тектонических перемещений. Кроме того, в наших исследованиях была использована база выполненных ранее замеров ФГУП ВИОГЕМ, насчитывающая более 17000 данных, относительно равномерно покрывающих карьерное поле.

Классификация трещиноватости Ковдорского бадделеит-апатит-магнетитового месторождения (КБАММ) проведена по трем основным признакам: парагенезизу, структурно-формационной иерархии, а также характеру и стадийности кинематики. Первый признак позволил разделить всю трещиноватость на две большие группы: прототектонический парагенезис, включающий трещиноватость этапов «собственно магматического (позднемагматического) - контракционного генезиса», и парагенезис наложенной тектоники посткарбонатитовых этапов, включающий трещины выветривания и разгрузки приповерхностного слоя. Более дробное рассчленение этой структуры с выделением в группах различных подтипов и стадий на данном этапе исследований нецелесообразно. По отношению к месторождению элементы трещинной тектоники классифицируются на «внутриформационные» (т.е. развитые только в пределах месторождения) и «трансформационные» соответственно. По характеру развития выделяются монокинематические - одноактного образования и мультикинематические, испытавшие минимум два этапа деформаций. Внутриформационная парагенетическая ассоциация в масштабах всего КБАММ имеет представительность 90-95 \% (авторская оценка) и включает следующие основные системы пород: радиальную с углами падения 65-90º кольцевую субвертикальную (тангенциальную) с углами падения 70-90 и две диагонально-конические: центриклинальную, падающую радиально к центру мас-

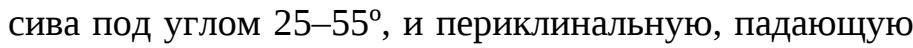
радиально от центра массива под углом 0-45․ Система субгоризонтальных трещин проявлена незначительно (преимущественно в приповерхностной части).

Формирование и развитие трещиноватости месторождения разнообразно по генезису, иерархической соподчиненности парагенетических ассоциаций и отдельных элементов трещинной тектоники и происходило полистадийно. Следствием этого является пре- 


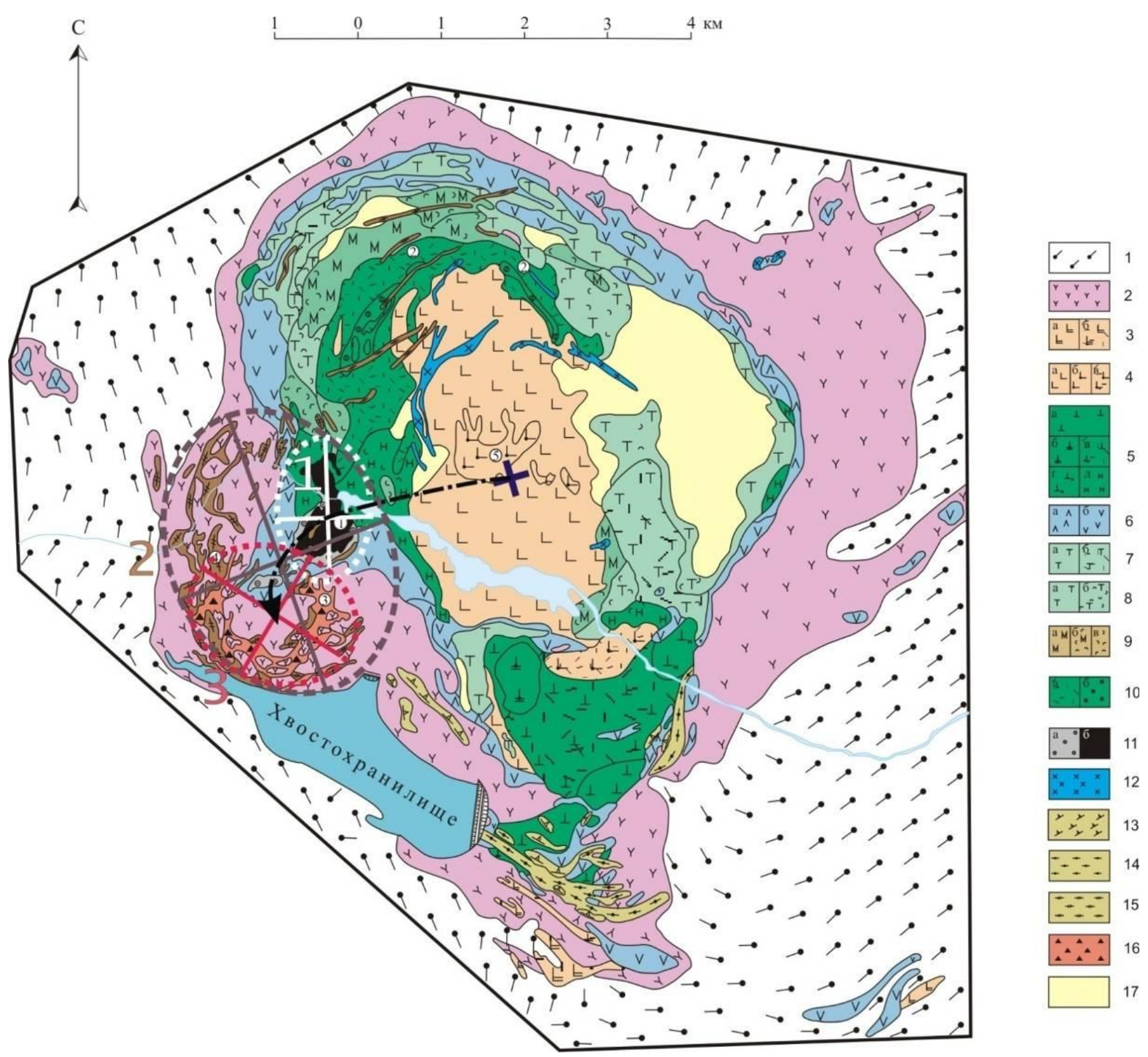

Рис. 3. Геологическая карта Ковдорского массива (составлена Б.В. Афанасьевым и др. [Мультимедийный справочник..., 2001] с добавлениями). 1 - гнейсы, амфиболиты и мигматиты архейского беломорского комплекса; 2 - фениты; 3: а - метаоливиниты, б - ослюденелые метаоливиниты; 4: а - оливиниты, б - рудные оливиниты, в - ослюденелые рудные пироксениты; 5: а - пироксениты и рудные пироксениты, б - пегматоидные рудные пироксениты, в - ослюденелые рудные пироксениты, г -нефелинизированные рудные пироксениты, д нефелин-пироксеновые породы по гипербазитам; 6: а - мельтейгиты, б -ийолиты» 7: а - турьяиты, б - ослюденелые турьяиты; 8: а - пироксен-мелилитовые породы, б - скарнированные пироксен-мелилитовые породы; 9: а - монтичеллитовые породы, б - скарнированные монтичеллитовые породы, в - гранат-амфибол-диопсидовые скарноподобные породы с монтичеллитом и везувианом; 10: а - амфиболфлогопит-форстеритовые породы, б - флогопитовые руды; 11: а - апатит-флогопит-форстеритовые породы (маложелезистые апатитовые руды), б - бадделеит-апатит-магнетитовые руды; 12 - нефелиновые сиениты; 13 - кальцит-апатит-флогопитовые породы; 14 -эгиринбиотит-карбонатитовые карбонатиты; 15 - форстерит-кальцитовые карбонатиты; 16: апатит-штаффелитовые руды; 17 - четвертичные отложения. Цифры в кружках - месторождения: 1 - апатит-магнетитовое, 2 - вермикулит-флогопитовое, 3 - апатит-штаффелитовое, 4 - рудных оливинитов.

Fig. 3. Geological map of the Kovdor block (modified by B.V. Afanasjev from [Multi-Media Guidebook ..., 2001]). 1 - gneisses, amphiboles and migmatites of the Archean Belomorsky series; 2 - fenites; 3: a - metaolivinites, $\sigma$ - mica metaolivinites; 4: a - olivinites, 6 - ore olivinites, в - mica ore pyroxenites, $\Gamma$ - nephelinic ore pyroxenites, $\mathrm{B}$ - nepheline-pyroxene rocks as per hyperbasites; 5 : a - pyroxenites and ore pyroxenites, $\sigma$ - pegmatoid ore pyroxenites, в - mica ore pyroxenites, $г$ - nephelinized ore pyroxenites, д - nepheline-pyroxene rocks by hyperbasites; 6 : a - melteigites, 6 - iyolites; 7: a - hydrohematite (turiyaites), 6 - mica hydrohematites; 8: a - pyroxene-melilitics rocks, б - scarn pyroxene-melilitics rocks; 9: a montichellite rocks, $\sigma$ - scarn montichellite rocks, в - garnet-amphibole-diopside scarn-like rocks with montichellite and vesuvian; 10: a - amphibole-phlogopite-fosterite rocks, $б$ - phlogopite ores; 11: a - apatite-phlogopite-forsterite rocks (low-ferric apatite ores), 6 - baddeleyite-apatitemagnetite ores; 12 - nephelinic syenite; 13 - calcium-apatite-phlogopite rocks; 14 - aegirine-biotite-carbonatite carbonatites; 15 - fosterite-calcite carbonatites; 16 - apatite-shtaffelite ores; 17 - Quaternary sediments. Numbers in circles show fields: 1 - apatite-magnetite, 2 - vermiculitephlogipite, 3 - apatite-shtaffelite, 4 - ore olivinites. 


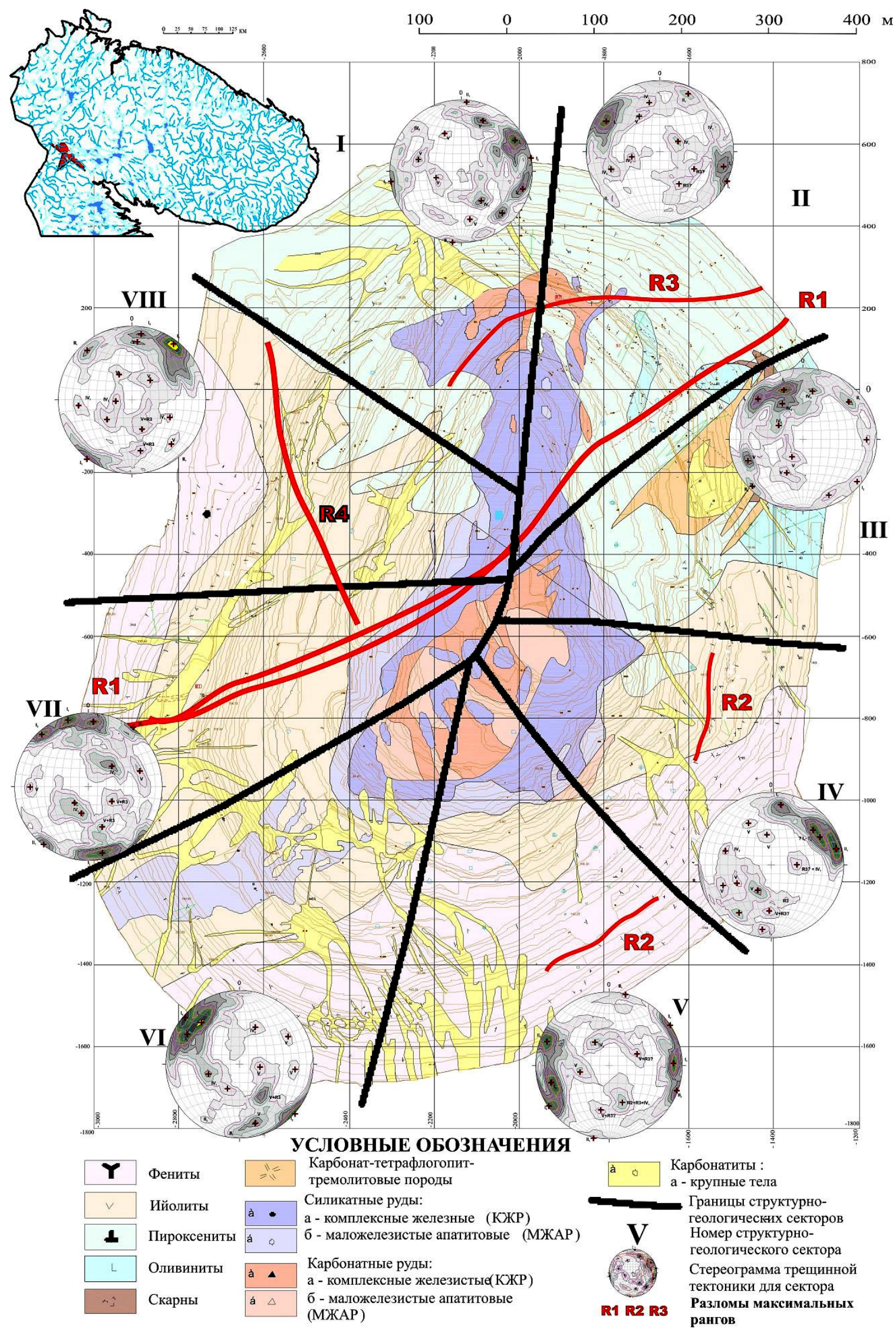

Рис. 4. Схема инженерно-геологического районирования рудника «Железный». На врезке показано положение Ковдорского месторождения в пределах Кольского полуострова.

Fig. 4. Engineering geological zonation of the Zhelezny mining site. Inset shows the position of Kovdor ore deposit in the frame of Kola Peninsula. 


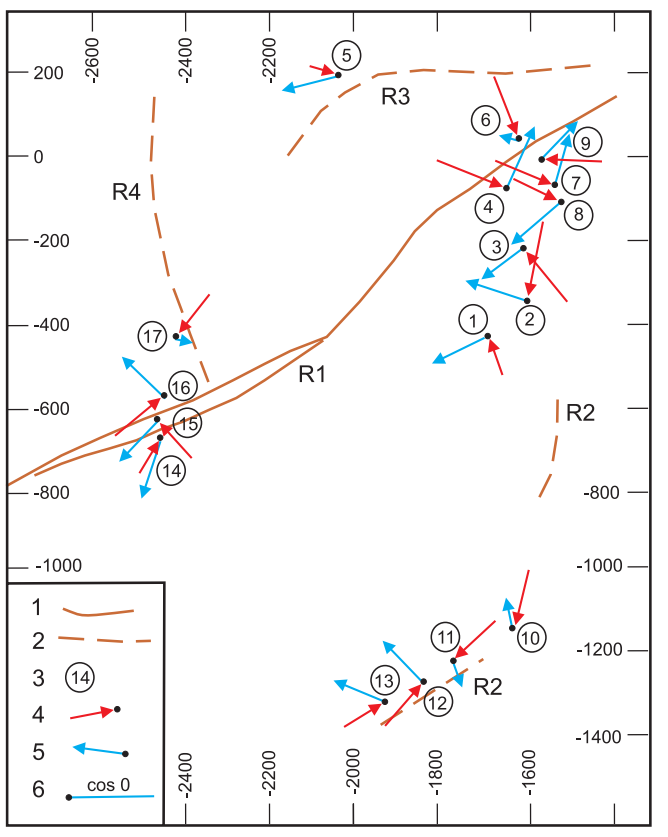

Рис. 5. Схема локальных осей сжатия и растяжения (рудник «Железный»), Ковдорский массив. 1 - разлом $\mathrm{R}_{1}$ - максимально активный в молодом поле напряжений; 2 - прочие разломы; 3 - однородно-нагруженные объемы и их номера; 4-5 - оси локальных главных нормальных напряжений: 4 - сжатия, 5 - растяжения; 6 косинус угла наклона осей напряжений $0^{\circ}$.

Fig. 5. Scheme of local axis of compression and extension for the Zhelezny mining site of the Kovdor block. 1 - fault $\mathrm{R}_{1}$ which is most active in the young field of stresses; 2 - other faults; 3 - volumes subject to regular loading and their numbers; $4-5$ - axes of local main normal stresses: 4 - compression, 5 - extension; 6 - cosine of stress axis inclination angle of $0^{\circ}$.

имущественно комбинаторно-наложенный тип распределения индивидуальных трещин и зон трещиноватости различных систем и парагенетических ассоциаций в массиве пород.

На Ковдорском бадделеит-апатит-магнетитовом месторождении трещинная тектоника и трещиноватость изучались с применением системы многопараметрической индексированной документации (азимутальные, морфометрические, геометрические и статистические характеристики), которая предоставляет широкие возможности дифференцированной статистической обработки с возможностью фильтрации выборки по заданному набору параметров. Применение этой методики позволило выявить закономерную изменчивость азимутальных характеристик парагенетической ассоциации систем прототектонических трещин в зависимости от положения относительно геометрического центра рудного штока. Выявленная закономерность положена в основу инженерно-структурного районирования месторождения по секториальному принципу (рис. 4). Каждый из восьми выделенных в пределах карьерного поля (см. стереограммы на рис. 4, сетка
Ламберта, нижняя полусфера) секторов имеет закономерно ориентированную по месту своего расположения прототектоническую парагенетическую ассоциацию, а также в большей или меньшей степени проявленную парагенетическую(ие) ассоциацию(ии) наложенной тектоники посткарбонатитовых этапов. Стереограммы секторов построены на выборках массовых замеров, включающих сотни структурных элементов, задокументированных авторами в 2008-2010 гг. и ранее - силами специалистов ФГУП ВИОГЕМ.

Банк данных по бороздам скольжения состоит из 273 векторов на плоскостях со следами смещений, в дальнейшем именуемых «реализованными плоскостями». Ориентация, генезис и возраст плоскостей различный: прототектонические и тектонические трещины, контакты даек и жил, плоскости рассланцевания и др. На 32 плоскостях зафиксированы по два векторы перемещений, из них в 14 случаях удалось установить последовательность их формирования (молодые / древние). Как правило, к более молодым бороздам скольжения относятся здесь тонкие следы перемещений с преобладанием сдвиговой составляющей, в то время как к древним - более мощные, грубые борозды, часто параллельные линии падения плоскости сместителя, иногда сопровождающиеся переориентировкой минералов в планпараллельные структуры (гнейсовидные, рассланцованные, отчетливо трахитоидные и т.п.) согласно вектору перемещения. У этих грубых борозд знак смещения (взброс или сброс) часто определяется неуверенно.

Анализ векторов перемещений, согласно кинематическому методу (графический вариант), позволил выделить на исследованной площади 17 однороднонагруженных объемов. Они ограничены по структурным признакам (разные крылья разломов, крупных трещин, бока даек карбонатитов и т.д.). При этом к одному объему относились группы близлежащих точек в случае, если замеры в этих точках не противоречили нахождению единого поля напряжений. В каждом из них восстановлена ориентация осей главных нормальных напряжений, плоскости действия максимальных касательных напряжений (табл. 1). Необходимо отметить, что в массиве пород, вскрытых карьером, широкое развитие получили волнистые трещины прототектонического генезиса, на которых значительно меняются элементы залегания. Векторы перемещений, измеренные на одной из таких плоскостей (рис. 6, A, замеры 13а, б, в), находятся в согласии с найденными осями $\sigma_{1}$ и $\sigma_{3}$, несмотря на разброс их ориентировок.

В каждом объеме восстановлена ориентация осей и плоскости действия максимальных касательных напряжений (табл. 1). Ранее было показано, что резкое изменение ориентировок осей главных нормальных напряжений происходит в разных крыльях разломов и служит признаком активности разлома в восстановленном поле напряжений [Cuм, 1980, 2000]. Два объе- 
Т а б л и ц а 1. Ориентировка тектонических напряжений рудника «Железный» (Ковдорский массив)

$\mathrm{T}$ a b l e 1. Orientation of tectonic stresses on the Zhelezny mining site (Kovdor massive)

\begin{tabular}{|c|c|c|c|c|c|c|c|}
\hline № объема & $\begin{array}{l}\text { Точки } \\
\text { наблюдений }\end{array}$ & $\begin{array}{l}\text { Месторасположение } \\
\text { точек наблюдений }\end{array}$ & $\begin{array}{l}\sigma_{1}, \text { азимут и } \\
\text { угол падения, }\end{array}$ & $\begin{array}{l}\sigma_{2}, \text { азимут и угол } \\
\text { падения, }^{\circ}\end{array}$ & $\begin{array}{l}\sigma_{3}, \text { азимут и } \\
\text { угол падения, }\end{array}$ & $\begin{array}{l}\tau_{\text {max }}, \text { азимут и } \\
\text { угол падения, } \\
\text { тип } \\
\end{array}$ & $\begin{array}{l}\tau_{\max }, \text { азимут и } \\
\text { угол падения, } \\
\text { тип } \\
\end{array}$ \\
\hline 1 & 1,2 & восточный борт & $246 \angle 30$ & $91 \angle 60$ & $342 \angle 10$ & $\begin{array}{l}317 \angle 60 \\
\operatorname{lw}, 34\end{array}$ & $\begin{array}{l}193 \angle 43 \\
\text { pw, } 29\end{array}$ \\
\hline 2 & 3 & восточный борт & $286 \angle 15$ & $114 \angle 75$ & $194 \angle 0$ & $\begin{array}{l}150 \angle 80 \\
l w, 10\end{array}$ & $\begin{array}{l}55 \angle 80 \\
\text { pw, } 10\end{array}$ \\
\hline 3 & 3a, 4 & восточный борт & $232 \angle 45$ & $58 \angle 46$ & $325 \angle 4$ & $\begin{array}{l}106 \angle 56 \\
l w, 27\end{array}$ & $\begin{array}{l}359 \angle 64 \\
\text { psw, } 32\end{array}$ \\
\hline 4 & 5 & восточный борт & $16 \angle 30$ & $220 \angle 60$ & $110 \angle 10$ & $\begin{array}{l}248 \angle 62 \\
\operatorname{lw}, 18\end{array}$ & $\begin{array}{l}150 \angle 80 \\
\text { ps, } 25\end{array}$ \\
\hline 5 & $7 a$ & $\begin{array}{l}\text { северо-восточный и } \\
\text { северный борт }\end{array}$ & $258 \angle 25$ & $356 \angle 20$ & $118 \angle 58$ & $\begin{array}{l}272 \angle 73 \\
\text { ls, } 65\end{array}$ & $\begin{array}{l}38 \angle 27 \\
\text { ps, } 16\end{array}$ \\
\hline 6 & 8 & $\begin{array}{l}\text { северо-восточный и } \\
\text { северный борт }\end{array}$ & $278 \angle 80$ & $62 \angle 10$ & $153 \angle 5$ & $\begin{array}{l}144 \angle 52 \\
l w, 50\end{array}$ & $\begin{array}{l}345 \angle 42 \\
\text { pw, } 40\end{array}$ \\
\hline 7 & 9 & $\begin{array}{l}\text { северо-восточный и } \\
\text { северный борт }\end{array}$ & $30 \angle 35$ & $148 \angle 36$ & $270 \angle 35$ & $\begin{array}{l}240 \angle 89 \\
l w, 85\end{array}$ & $\begin{array}{l}148 \angle 36 \\
\text { pw, } 2\end{array}$ \\
\hline 8 & 10,11 & $\begin{array}{l}\text { северо-восточный и } \\
\text { северный борт }\end{array}$ & $231 \angle 20$ & $345 \angle 44$ & $125 \angle 40$ & $\begin{array}{l}265 \angle 78 \\
\text { ls, } 40\end{array}$ & $\begin{array}{l}7 \angle 45 \\
\text { ps, } 12\end{array}$ \\
\hline 9 & 12 & $\begin{array}{l}\text { северо-восточный и } \\
\text { северный борт }\end{array}$ & $15 \angle 30$ & $214 \angle 60$ & $110 \angle 10$ & $\begin{array}{l}\overline{244 \angle 62} \\
\mathrm{lw}, 14\end{array}$ & $\begin{array}{l}145 \angle 78 \\
\text { pw, } 30\end{array}$ \\
\hline 10 & 13 & юго-восточный борт & $351 \angle 70$ & $102 \angle 10$ & $197 \angle 18$ & $\begin{array}{l}188 \angle 63 \\
l w, 60\end{array}$ & $\begin{array}{l}29 \angle 28 \\
\text { pw, } 25\end{array}$ \\
\hline 11 & 15 & юго-восточный борт & $161 \angle 70$ & $308 \angle 18$ & $40 \angle 10$ & $\begin{array}{l}25 \angle 58 \\
\mathrm{lw}, 52\end{array}$ & $\begin{array}{l}237 \angle 38 \\
\text { pw, } 35\end{array}$ \\
\hline 12 & 16 & юго-восточный борт & $316 \angle 25$ & $123 \angle 66$ & $223 \angle 15$ & $\begin{array}{l}180 \angle 76 \\
\text { lw, } 20\end{array}$ & $\begin{array}{l}86 \angle 70 \\
\text { pw, } 15\end{array}$ \\
\hline 13 & 17 & юго-восточный борт & $302 \angle 40$ & $176 \angle 40$ & $56 \angle 30$ & $\begin{array}{l}186 \angle 40 \\
\operatorname{lw}, 12\end{array}$ & $\begin{array}{l}88 \angle 85 \\
\text { pw, } 50\end{array}$ \\
\hline 14 & 18 & западный борт & $204 \angle 30$ & $296 \angle 2$ & $27 \angle 60$ & $\begin{array}{l}205 \angle 76 \\
\mathrm{~s}\end{array}$ & $\begin{array}{l}25 \angle 15 \\
\mathrm{~s}\end{array}$ \\
\hline 15 & 19 & западный борт & $217 \angle 40$ & $46 \angle 51$ & $311 \angle 5$ & $\begin{array}{l}91 \angle 59 \\
\operatorname{lw}, 25\end{array}$ & $\begin{array}{l}346 \angle 68 \\
\text { pw, } 30\end{array}$ \\
\hline 16 & 20 & западный борт & $307 \angle 26$ & $154 \angle 62$ & $50 \angle 30$ & $\begin{array}{l}176 \angle 63 \\
l w, 10\end{array}$ & $\begin{array}{l}62 \angle 80 \\
\text { pw, } 25\end{array}$ \\
\hline 17 & 22,23 & западный борт & $102 \angle 70$ & $312 \angle 20$ & $218 \angle 20$ & $\begin{array}{l}15 \angle 42 \\
\operatorname{lw}, 32\end{array}$ & $\begin{array}{l}234 \angle 58 \\
\mathrm{pw}, 51\end{array}$ \\
\hline$*$ & & $\begin{array}{l}\text { Региональное поле } \\
\text { напряжений (1) }\end{array}$ & $220 \angle 65$ & $4 \angle 20$ & $98 \angle 15$ & $\begin{array}{l}82 \angle 62 \\
\mathrm{lw}, 53\end{array}$ & $\begin{array}{l}302 \angle 38 \\
\text { pw, } 32\end{array}$ \\
\hline$* *$ & & $\begin{array}{l}\text { Региональное поле } \\
\text { напряжений (2) }\end{array}$ & $4 \angle 20$ & $220 \angle 65$ & $98 \angle 15$ & $\begin{array}{l}140 \angle 84 \\
\text { pw, } 35\end{array}$ & $\begin{array}{l}233 \angle 66 \\
\operatorname{lw}, 7\end{array}$ \\
\hline
\end{tabular}

П р и м е ч а н и е. Азимут и угол погружения осей главных нормальных напряжений: $\sigma_{1}-$ ось растяжения, $\sigma_{2}-$ промежуточная ось, $\sigma_{3}-$ ось сжатия; $\tau_{\max }$ - азимут и угол падения плоскости действия максимальных касательных напряжений; кинематический тип: $\mathrm{w}-$ взброс, $\mathrm{s}$ - сброс, l - левый сдвиг, p - правый сдвиг.

$\mathrm{N}$ o t e. Azimuth and dip angle of major normal stresses: $\sigma_{1}-$ extension axis; $\sigma_{2}-$ transition axis; $\sigma_{3}-$ compression axis; $\tau_{\max }-$ azimuth and dip angle of the plane of maximum tangential stresses; kinematic type: $\mathrm{w}$ - reserve fault; $\mathrm{s}$ - normal fault, $\mathrm{l}$ - sinistral strike-slip fault; $\mathrm{p}$ - dextral strikeslip fault.

ма (№ 5, т.н. 7а; № 14, т.н. 18), для которых определены крутые оси сжатия, расположены максимально близко к разлому R1 и могут являться подтверждением его активности (рис. 5).

Данные о локальных стресс-состояниях позволяют сделать предварительные выводы о возможной дополнительной роли тектонических напряжений в обрушении на юго-восточном борту карьера «Железный». Выполненные в 2009 г. структурно-тектонические исследования показали наличие плоскостей крупных трещин вдоль стенки обрушения, которые падают в сторону карьера. На этих плоскостях практически отсутствуют следы тектонических перемещений. Ближайшая от обрушения точка, в которой восстановлены оси главных нормальных напряжений, показала, что вид напряженного состояния близок к одноосному растяжению (рис. 6 , $B$, объем № 10 , точка 13), что могло способствовать обрушению в сочетании с благоприятно ориентированными плоскостями трещиноватости. В 20-30 м на ВСВ от зоны обрушения в горных породах задокументированы трещины отрыва с характерной ребристой морфологией плоскости, на которой видно перистое расхождение «ребер», кальцитовая минерализация в породе и «дезинтеграция» карбонатита неясного генезиса до состояния дресвы. Вышеперечисленные и не свойственные для остальной части карьера особенности находятся в согласии с локальной обстановкой растяжения. К западу от стенки обруше- 
A

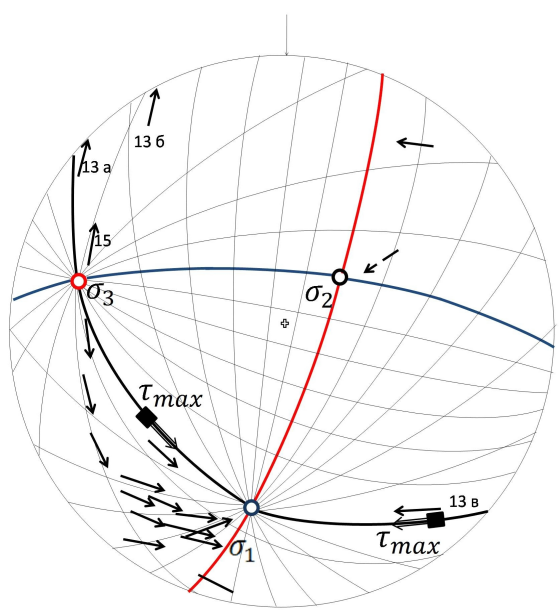

B

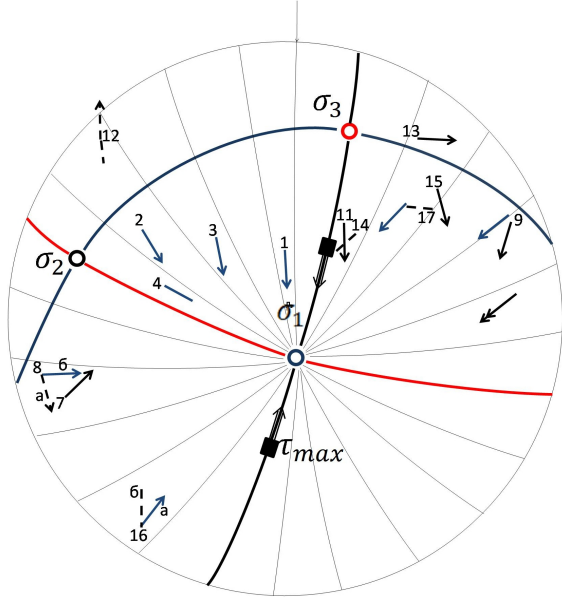

Рис. 6. Локальные стресс-состояния в однородно-нагруженных объемах (сетка Вульфа, верхняя полусфера): $A$ - № 4 (табл. 1), точка 5; $B$ № 10 (табл. 1), точка 13, юго-восточный борт карьера. 1 - оси главных нормальных напряжений и плоскости их действия: а - $\sigma_{1}-$ минимальных, $\sigma-\sigma_{2}-$ промежуточных, в - $\sigma_{3}$ - максимальных сжимающих; 2 - полюса плоскостей действия максимальных касательных напряжений; 3 - векторы перемещений в точке полюса плоскости с бороздами скольжения: а и б - соответствующие найденным осям $\sigma_{1}$ и $\sigma_{3}$, а - с определенным, б - с неопределенным знаком смещения; в - противоречащие найденным осям $\sigma_{1}$ и $\sigma_{3}$. Цифрами показаны номера замеров векторов перемещений.

Fig. 6. Local states of stresses in the volumes subject to regular loading. The Wulff net, upper hemisphere: $A$ - № 4 (Table 1 ), point 5 ; $B-$ № 10 (Table 1), Point 13, the SE side of the quarry. 1 - axes and planes of main normal stresses: a $-\sigma_{1}-$ minimum, $\sigma-\sigma_{2}-$ transitional, в $-\sigma_{3}-$ maximum compression; 2 - poles of planes of maximum tangential stresses; 3 - vectors of displacements at the pole point of the plane with striations: a and $\sigma$ - determined axes of $\sigma 1$ and $\sigma_{3}$, correspondingly (a - with determined sign, $\sigma$ - with undetermined sign); в - in contradiction to determined axes of $\sigma_{1}$ and $\sigma_{3}$. Numbers correspond to numbering of displacement vector measurements.

ния восстановлено локальное стресс-состояние с трехосным напряженным состоянием.

Данные о локальных стресс-состояниях позволили найти два варианта общего поля напряжений. Первый вариант (№ 1) для всего карьера имеет следующие характеристики: ось растяжения $\left(\sigma_{1}\right)$ крутая, азимут погружения $-220^{\circ} \angle 65^{\circ}$; ось сжатия $\left(\sigma_{3}\right): 98^{\circ} \angle 15^{\circ}$, проме жуточная ось $\left(\sigma_{2}\right): 4^{\circ} \angle 20^{\circ}$ (рис. 7 , табл. 1$)$. Плоскости действия максимальных касательных напряжений $\tau_{\max }$ - азимут падения $82^{\circ} \angle 62^{\circ}$, левый взбросо-сдвиг и азимут падения $302^{\circ} \angle 38^{\circ}$, правый взбросо-сдвиг. Вторая плоскость $\tau_{\max }$ достаточно хорошо соответствует разлому $\mathrm{R}_{3}$, имеющему азимут падения $303-305^{\circ} \angle 35^{\circ}$. Этому общему полю противоречит единственное определение оси растяжения в объеме № 2 (восточная стенка карьера), но, учитывая некоторую ненадежность этого определения из-за малого числа борозд скольжения и их слабой выраженности, этим противоречием можно пренебречь.

Второй вариант общего поля напряжений (№ 2) характеризуется переиндексацией промежуточной оси и оси сжатия, соответственно, оно характеризуется следующими параметрами: ось растяжения $-4^{\circ} \angle 20^{\circ}$, промежуточная ось крутая $-220^{\circ} \angle 65^{\circ}$; ось сжатия $\left(\sigma_{3}\right)$ : $98^{\circ} \angle 15^{\circ}$ (рис. 8, таблица 1). Плоскости действия максимальных касательных напряжений $\tau_{\max }-140^{\circ} \angle 84^{\circ}$, правый взбросо-сдвиг с примерно равными сдвиговой и взбросовой составляющими и азимут падения $233^{\circ} \angle 66^{\circ}$, левый взбросо- сдвиг с преобладанием сдвиговой составляющей смещения. Вторая плоскость $\tau_{\max }$ близка по положению в пространстве упомянутому выше разлому $\mathrm{R}_{1}$. Оси растяжения общего поля № 2 противоречат оси локального сжатия в объемах № 1 и № 2; оси сжатия в объемах № 3, 6 и 10 в принципе находятся в пределах ошибки определения осей (и измерений векторов перемещения). Обращает на себя внимание то, что все противоречащие сдвиговому общему полю определения локальных стресс-состояний находятся в восточном борту и, возможно, отвечают более древнему этапу развития.

Весьма важные уточнения относительно возрастных взаимоотношений взбросового и сдвигового полей напряжений внес анализ поясного распределения реализованных плоскостей. Произведенный расчет плотности плоскостей с векторами перемещений (рис. 9) показал, что эти плоскости образуют отчетливый пояс $\mathrm{PP}_{1}$ с полюсом $\mathrm{P}_{1}$ (аз. пад. $4^{\circ} \angle 20^{\circ}$ ) и что пояс образован двумя максимумами плотностей векторов, ограниченных изолинией 2 \%, вытянутыми вдоль пояса. Внутри максимумов, в свою очередь, проявлены по два локальных максимума. Так, в 1-м максимуме с плоскостями ССЗ простирания выделяются локальные 

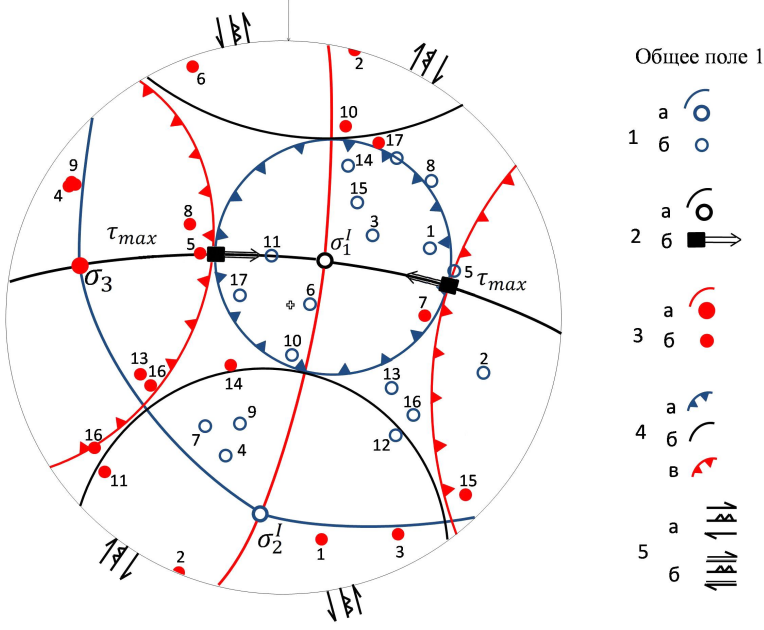

Рис. 7. Стереограмма общего поля напряжений № 1 (р-к «Железный»). $1 a-3 a-$ оси главных нормальных напряжений в однороднонагруженных объемах и плоскости действия осей общего поля: 1 растяжения, 2 - промежуточная, в - сжатия; 16 и $3 б$ - оси сжатия (1б) и растяжения (3б) однородно-нагруженных объемов, 26 - полюса плоскостей действия максимальных касательных напряжений; 4 - конусы: а - сжатия, б - промежуточных осей, в - растяжения; 5 - простирание плоскостей действия максимальных касательных напряжений и кинематические типы: а - взбросо-сдвиги, б - сдвиго-взбросы.

Fig. 7. Stereogram of the general stress field № 1 (Zhelezny mining site). $1 a-3 a-$ axes of main normal stresses in the volumes subject to regular loading, and planes of axes of the general field: 1 - extension, 2 - transitional, в - compression; 16 and Зб - axes of compression (1б) and extension (3б) of the volumes subject to regular loading; $2 \sigma$ - poles of planes of maximum tangential stresses; $4 a$ - compression cone; 46 cone of transitional stresses; $4 b$ - extension cone; 5 - strike of planes of maximum tangential stresses and kinematic types: $5 a$ - strike-slip faults with reverse component, $5 \sigma$ - reverse faults with shear component.

максимумы плоскостей с аз. пад. $220^{\circ} \angle 75^{\circ}$ и аз. пад. $264^{\circ} \angle 80^{\circ}$, которые оконтуриваются изолиниями в 3 и 6 \%; во 2-м максимуме с плоскостями СВ простирания два локальных максимума, которые оконтурены изолинией в $2.5 \%$, имеют: аз. пад. $144^{\circ} \angle 80^{\circ}$ (восемь плоскостей) и $115^{\circ} \angle 75^{\circ}$ (семь плоскостей). Два локальных максимума (с плотностью в $2.5 \%$ (координаты $144^{\circ} \angle 80^{\circ}$ ) и с плотностью $3 \%$ (координаты $220^{\circ} \angle 75^{\circ}$ ) близки к плоскостям действия касательных напряжений $\tau_{\max }$ на плоскости действия оси растяжения найденного взбросового поля.

Ось пояса реализованных плоскостей с бороздами скольжения (условной трещиноватости, так как векторы фиксируются и на плоскостях рассланцевания, и на контактах жил и т.д.) близка к положению промежуточной оси сдвигового поля напряжений № 2. На рис. 8 промежуточная ось сдвигового поля напряжений находится вблизи оси пояса трещин, что может указывать, согласно С.И. Шерману [Шерман, 1966], на образование пояса трещин при перемещении по раз-

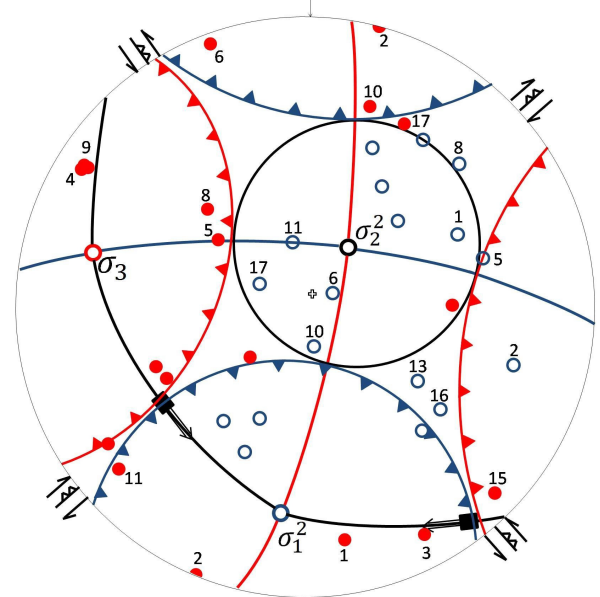

Общее поле 2

Рис. 8. Стереограмма общего поля напряжений № 2. Условные обозначения на рис. 7 .

Fig. 8. Stereogram of the general stress field № 2. Legend same as in Figure 7.

лому $\mathrm{R}_{1}$ именно в этом сдвиговом поле напряжений.

По методике В.Н. Даниловича соединяются точки простирания разлома $\mathrm{R}_{1}$ на внешнем круге стереограммы с точкой $\mathrm{P}_{1}$ (полюс пояса трещин) и восстанавливается генеральное положение плоскости данного разлома (аз. пад. $152^{\circ} \angle 75^{\circ}$ ), что согласуется с данными картирования этого разлома в бортах карьера. Расхождение вычисленных параметров разлома на $10^{\circ}$ от данных измерения плоскости сместителя в карьере допустимо из-за его сложного строения с разветвлением плоскости в приповерхностной части и сложной морфологии. По кинематическому типу он является правым взбросо-сдвигом с явным преобладанием сдвиговой компоненты и с поднятым юго-восточным крылом. Точка $\mathrm{K}_{1}$, лежащая на пересечении главной кинематической плоскости (или плоскости действия оси промежуточных напряжений) с плоскостью разлома, показывает выход векторы $\mathrm{K}_{1} \mathrm{O}$ - направление перемещения по плоскости разлома в поле напряжений № 2 - на верхнюю полусферу; отрезок дуги $\mathrm{KK}_{1}$ является интервалом разброса возможных перемещений по разлому с учетом данных о поясном распределении реализованных плоскостей и реконструкции палеонапряжений. В более древнем взбросовом поле № 1 разлом $\mathrm{R}_{1}$ при падении на ЮВ являлся сдвиго-взбросом с подчиненной право- или левосдвиговой компонентой перемещения в зависимости от величины $\mu \sigma$.

Общепринято, что большинство борозд скольжения отражает следы последних перемещений на зеркалах скольжения. Соответственно, концентрация реализованных плоскостей по всему карьеру вблизи плоскостей действия максимальных касательных напряжений сдвигового общего поля напряжений подтверждает сделанные ранее выводы о его более молодом возрас- 


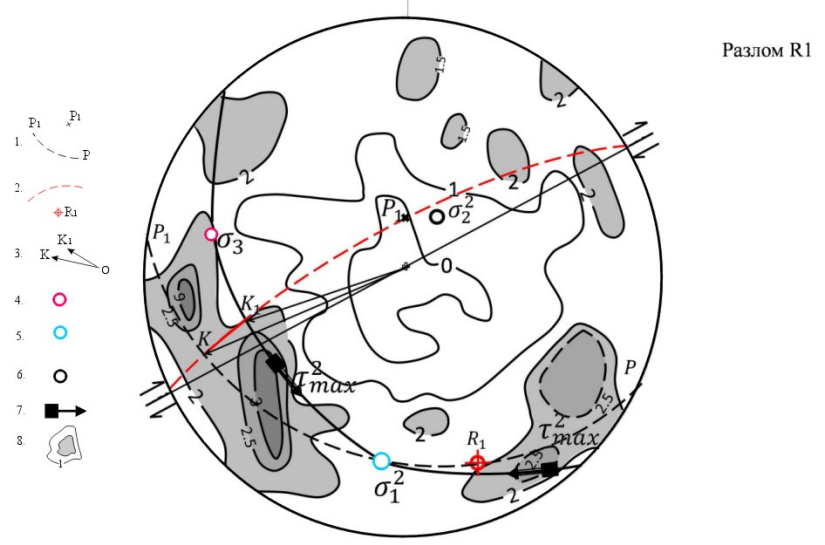

Рис. 9. Поясное распределение полюсов плоскостей с бороздами скольжения и определение кинематического типа разлома на руднике «Железный», Ковдорский массив (сетка Вульфа, верхняя полусфера). 1 - пояс реализованных плоскостей $\mathrm{PP}_{1}$ и его ось (полюс) $\mathrm{P}_{1} ; 2$ - плоскость разлома и его полюс $\mathrm{R}_{1} ; 3$ - векторы перемещений в плоскости разлома, определенные согласно: КО - поясному распределению трещиноватости, $\mathrm{K}_{1} \mathrm{O}$ - ориентировке осей главных нормальных напряжений общего поля II; 4-6 - оси максимальных (4), промежуточных (5) и минимальных (6) сжимающих главных нормальных напряжений II поля; 7 - полюса плоскостей действия максимальных касательных напряжений; 8 - изолинии плотности трещин с бороздами скольжения.

Fig. 9. Belt-type distribution pattern of poles of planes with striations, and determination of the kinematic type of the fault at the Zhelezny mining site of the Kovdor block. The Wulff net, upper hemisphere. 1 belt of actual planes of $\mathrm{PP}_{1}$ and axis (pole) of $\mathrm{P}_{1} ; 2$ - fault plane and pole of $\mathrm{R}_{1} ; 3$ - vectors of displacements at fault plane that are determined from: $\mathrm{KO}$ - belt-type fracturing pattern, $\mathrm{K}_{1} \mathrm{O}$ - orientation of axes of main normal stresses of General Stress Field II; 4-6 - axes of maximum (4), transitional (5) and minimum (6) compression of main normal stresses of General Stress Field II; 7 - poles of planes of maximum tangential stresses; 8 - isolines of density of fractures with striations.

те. В свою очередь, отсутствие максимумов реализованных плоскостей, близких по положению в пространстве к плоскостям максимальных касательных напряжений взбросового поля, также не противоречит тезису о его более древнем возрасте. Общая северовосточная ориентация субгоризонтальных осей сжатия в лежачем крыле прототектонической трещины (разлома), по которому произошло обрушение, а также крутые оси растяжения при условии, что т.н. 13 близка к СВ концу разлома, соответствуют правосдвиговому перемещению по этой плоскости в общем молодом поле напряжений. При этом положение плоскости обрушения по отношению к плоскостям действия максимальных касательных напряжений этого последнего поля значительно менее благоприятно для активизации по сравнению с положением разлома $\mathrm{R}_{1}$.

Из сопоставления данных по трещиноватости с «реализованными плоскостями» очевидно, что в новейшем поле напряжений из множества систем разно- возрастных трещин происходит их избирательная активизация - борозды скольжения образуются только на трещинах, благоприятно ориентированных относительно осей общего молодого поля напряжений.

Изучение разломной тектоники, трещиноватости и тектонических напряжений на руднике «Железный» дало возможность выделить этапы хрупкопластического деформирования исследованной части Ковдорского массива (рис. 10). Первый этап соответствует начальной стадии образования прототектонических трещин; второй - ранний посткарбонатитовый (после завершения магматизма с ранними карбонатитами). К этой стадии относится внедрение даек поздних карбонатитов и формирование разлома $\mathrm{R}_{1}$, крутое падение которого дает возможность предположить сдвиговое поле на этом этапе; по преобладающей ориентировке даек карбонатитов можно предположить субширотную ориентировку оси растяжения. Последние стадии C и D восстановлены с помощью изучения тектонических напряжений.

Хибинский щелочной массив приурочен к тектоническому контакту Имандра-Варзугской зоны карелид (на юге и западе массива) и архейских гранитогнейсов Центрально-Кольского домена. Он локализован в трансрегиональной северо-восточной зоне, пересекающей весь Кольский п-ов и протягивающейся до грабена Осло. К пересечению долгоживущих глубинных разломов этой зоны с разломами других простираний тяготеют интрузии щелочно-ультраосновных пород и нефелиновых сиенитов. Хибинский массив является многофазным эллипсовидным в плане плутоном, длинная ось которого протяженностью 45 км вытянута по азимуту В 82; меридиональная ось равна 35 км (рис. 11). Морфологически он близок к асимметричному лополиту, у которого крутые контакты - восточный и северный, более пологие - южный и западный. На глубине он переходит в коническую структуру центрального типа. Внутреннее строение массива многофазное концентрически-зональное, от периферии к центру породы разного состава сменяют друг друга [Геология..., 2002].

Основные тектонофизические работы были проведены на месторождении Олений Ручей (рис. 11) в восточной части Хибинского массива нефелиновых сиенитов, на котором выделены четыре локальных стресссостояния кинематическим методом и два - методом выделения сопряженных сколов (табл. 2).

Общим для этих стресс-состояний является пологая ось сжатия, ориентировка которой меняется от субширотной (точки 1 и 7а) до СС3 (точки 6, 7 и 9Q) и субмеридиональной до СВ растяжения, угол наклона которой меняется от пологого (т.н. 9Q ) через наклонное (т.н. 7) до крутого (т.н. 6). Исключением является стресс-состояние в т.н. 8, расположенной на ЮВ крутом склоне г. Суолуайв южнее рудника. Локальное стресс-состояние в этой точке характеризуется пологой СВ ориентировкой оси сжатия и СЗ пологой - рас- 

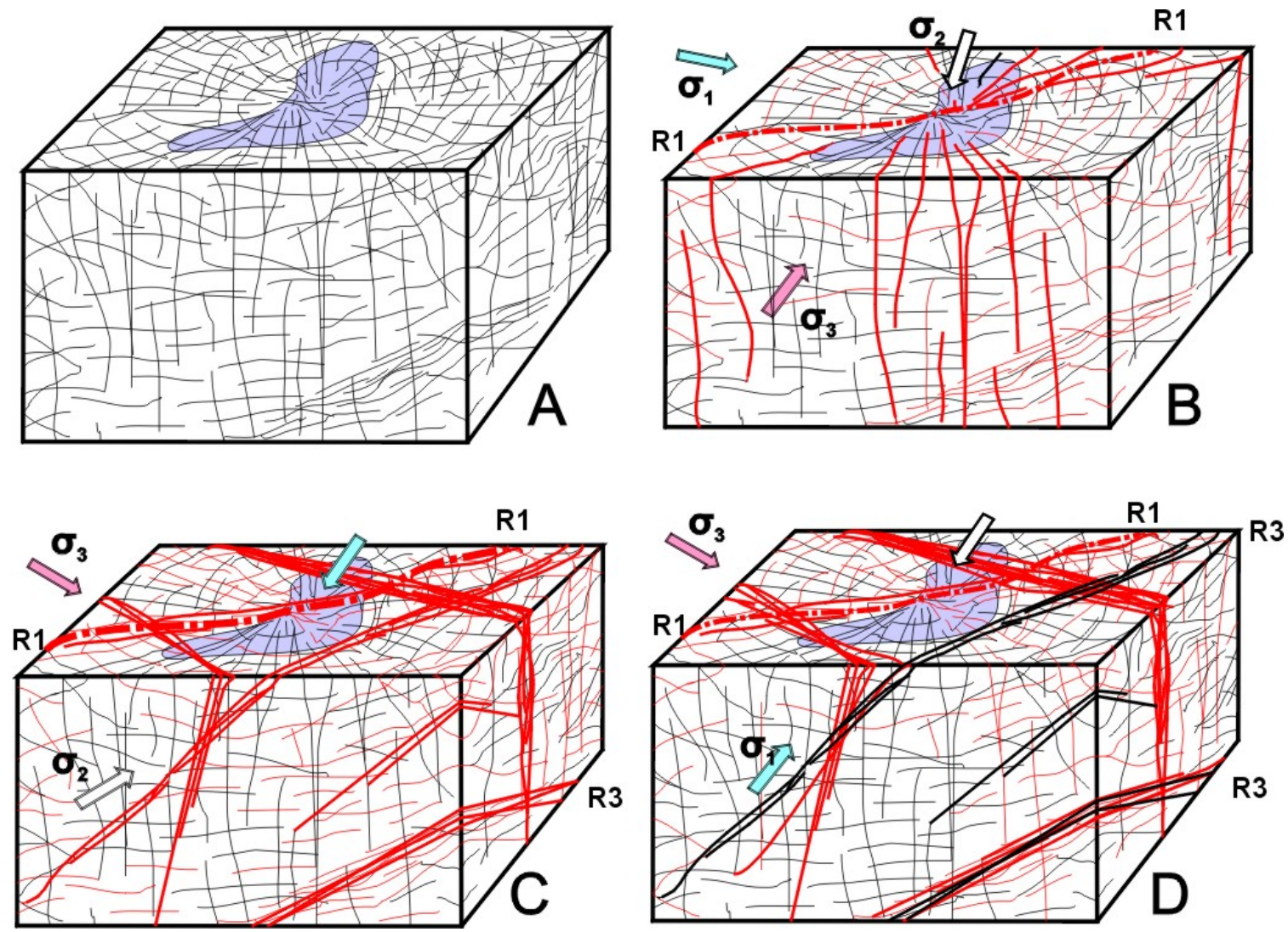

Рис. 10. Этапы хрупко-пластического деформирования интрузии с апатит-магнетитовым месторождением (Ковдорский массив) [Жиров, Сuм, 2010]: $A$ - этап формирования прототектонических трещин; $B$ - этап образования разлома $\mathrm{R}_{1}$, первых систем тектонических трещин, внедрение даек поздних карбонатитов; $C$ - первый постмагматический этап, соответствующий установленному тектонофизическими методами 1-му полю напряжений; $D$ - неотектонический этап, соответствует 2-му сдвиговому полю напряжений.

Fig. 10. Stages of brittle-plastic deformation of the intrusion with apatite-magnetite deposit (Kovdor block) [Жupoв, Cuм, 2010]: $A$ - phase of prototectonic fracturing; $B$ - phase of formation of fault $\mathrm{R}_{1}$, the first systems of tectonic fractures, penetration of dykes of late carbonatites; $C$ the first postmagmatic phase corresponding to Stress Field I which is revealed by tectonophysical methods; $D$ - neotectonic phase which corresponds to Stress Field II (strike-slip).

тяжения, практически соответствующей ориентировке оси сжатия в т.н. 7 и 9Q (табл. 2, рис. 12). Такая переиндексация локальных осей главных нормальных напряжений характерна для разных крыльев разломов. Гора Суолуайв расположена в лежачем ЮЮВ крыле обновленного сложнопостроенного разлома, относящегося к краевым разломам Хибинского массива, частично вскрывающегося в т.н. 7. В последней, где вскрышные работы на карьере обнажили первые апатитовые тела, разлом представлен зоной дробления и интенсивной шпреуштейнизацией. Крутая ось растяжения в т.н. 6, возможно, также обусловлена влиянием небольшого разлома с азимутом простирания С3 305$325^{\circ}$, который разработан левым притоком Оленьего ручья.

На рис. 12 (точка 9Q) представлен вариант определения локального стресс-состояния по трещинам в четвертичных водно-ледниковых отложениях, вскрытых в восточном борту дороги при въезде на карьер.
Реконструкция тектонических напряжений в т.н. 7 также была произведена с помощью выделения сколовых сопряженных трещин (объем 7а). Угол наклона осей сжатия и растяжения стресс-состояний, определенных разными методами, сохраняется пологий, но субмеридиональная ось растяжения разворачивается от меридиональной (в определении № 7 a $13^{\circ} \angle 20^{\circ}$ ) до Ю3 (в определении № 7 на $226^{\circ} \angle 30^{\circ}$ ). Азимут погружения оси сжатия меняется от ЗС $283^{\circ}$ до С $320^{\circ}$. Сравнение результатов реконструкции локальных стресс-состояний на руднике «Олений Ручей», несмотря на малое количество определений, показывает в целом доминирование сдвигового поля напряжений с усредненной ЗСЗ ориентировкой оси сжатия и субмеридиональной осью растяжения (пять определений из шести). Относительная непротиворечивость определений локальных стресс-состояний, восстановленных в коренных и четвертичных породах, позволяет говорить, по сути, о современном поле напряжений, вос- 
Т а б л и ц а 2. Ориентировка тектонических напряжений Кольского полуострова

$\mathrm{T}$ a b l e 2. Orientation of tectonic stresses of the Kola Peninsula

\begin{tabular}{|c|c|c|c|c|c|c|c|}
\hline № & $\begin{array}{l}\text { Точка } \\
\text { наблю- } \\
\text { дений }\end{array}$ & Район & $\begin{array}{l}\sigma_{1}, \text { азимут } \\
\text { и угол } \\
\text { падения, }^{\circ}\end{array}$ & $\begin{array}{l}\sigma_{2}, \text { азимут } \\
\text { и угол } \\
\text { падения, }^{\circ}\end{array}$ & $\begin{array}{l}\sigma_{3}, \text { азимут } \\
\text { и угол } \\
\text { падения }{ }^{\circ}\end{array}$ & $\begin{array}{l}\tau_{\max }, \text { азимут и } \\
\text { угол падения, }{ }^{\circ} \text {, } \\
\text { тип }\end{array}$ & $\begin{array}{l}\tau_{\max }, \text { азимут и } \\
\text { угол падения, 。, } \\
\text { тип }\end{array}$ \\
\hline 1 & 1 & Олений ручей (карьер «СЗФК») & $218 \angle 20$ & $338 \angle 54$ & $116 \angle 30$ & $\begin{array}{l}346 \angle 54 \\
\text { ps }\end{array}$ & $\begin{array}{l}258 \angle 85 \\
\text { ls }\end{array}$ \\
\hline 2 & 3 & $\begin{array}{l}\text { г. Поачвумчорр } \\
\text { (к северу от г. Кировска) }\end{array}$ & $350 \angle 20$ & $96 \angle 30$ & $232 \angle 55$ & $\begin{array}{l}14 \angle 60 \\
\text { ls }\end{array}$ & $\begin{array}{l}134 \angle 35 \\
\text { ps }\end{array}$ \\
\hline 3 & 4 & г. Мурманск, карьер & $118 \angle 10$ & $254 \angle 76$ & $27 \angle 10$ & $\begin{array}{l}242 \angle 88 \\
\operatorname{lw}\end{array}$ & $\begin{array}{l}252 \angle 76 \\
\mathrm{p}\end{array}$ \\
\hline 4 & 5 & Пулозеро, в выемке дороги М18 & $219 \angle 60$ & $61 \angle 28$ & $326 \angle 10$ & $\begin{array}{l}115 \angle 43 \\
\text { lw }\end{array}$ & $\begin{array}{l}350 \angle 59 \\
\text { pw }\end{array}$ \\
\hline 5 & 6 & Олений ручей (карьер «СЗФК») & $336 \angle 88$ & $242 \angle 2$ & $154 \angle 2$ & $\begin{array}{l}332 \angle 40 \\
\mathrm{w}\end{array}$ & $\begin{array}{l}152 \angle 48 \\
\mathrm{w}\end{array}$ \\
\hline 6 & 7 & Олений ручей (карьер «СЗФК») & $226 \angle 30$ & $67 \angle 56$ & $320 \angle 10$ & $\begin{array}{l}99 \angle 60 \\
\operatorname{lw}\end{array}$ & $\begin{array}{l}359 \angle 74 \\
\text { pw }\end{array}$ \\
\hline 7 & $7 a$ & Олений ручей (карьер «СЗФК») & $13 \angle 20$ & $144 \angle 60$ & $283 \angle 25$ & $\begin{array}{l}63 \angle 87 \\
\text { ls }\end{array}$ & $\begin{array}{l}144 \angle 60 \\
\mathrm{p}\end{array}$ \\
\hline 8 & 8 & $\begin{array}{l}\text { Олений ручей (естественное обнаже- } \\
\text { ние) }\end{array}$ & $324 \angle 13$ & $234 \angle 10$ & $107 \angle 74$ & $\begin{array}{l}190 \angle 86 \\
\underline{\mathrm{lw}}\end{array}$ & $\begin{array}{l}100 \angle 72 \\
\mathrm{p}\end{array}$ \\
\hline 9 & $9 Q$ & Олений ручей (карьер «СЗФК») & $60 \angle 2$ & $141 \angle 72$ & $320 \angle 20$ & $\begin{array}{l}\overline{184} \angle 78 \\
\mathrm{p}\end{array}$ & $\begin{array}{l}96 \angle 76 \\
1\end{array}$ \\
\hline 10 & 10 & $\begin{array}{l}\text { Рудник «Центральный» (верхняя } \\
\text { часть) }\end{array}$ & $324 \angle 20$ & $174 \angle 67$ & $58 \angle 10$ & $\begin{array}{l}194 \angle 70 \\
1\end{array}$ & $\begin{array}{l}100 \angle 83 \\
\mathrm{p}\end{array}$ \\
\hline 11 & 11 & Рудник «Восточный» (Коашва) & $29 \angle 18$ & $296 \angle 6$ & $197 \angle 68$ & $\begin{array}{l}220 \angle 23 \\
\mathrm{~s}\end{array}$ & $\begin{array}{l}26 \angle 66 \\
\text { ls }\end{array}$ \\
\hline 12 & $11 \mathrm{a}$ & Рудник «Восточный» (Коашва) & $16 \angle 10$ & $281 \angle 28$ & $124 \angle 60$ & $\begin{array}{l}353 \angle 58 \\
\text { ps }\end{array}$ & $\begin{array}{l}226 \angle 43 \\
\text { ls }\end{array}$ \\
\hline 13 & $11 \mathrm{Q}$ & Рудник «Восточный» (Коашва) & $282 \angle 17$ & $138 \angle 70$ & $16 \angle 12$ & $\begin{array}{l}58 \angle 86 \\
\text { pw }\end{array}$ & $\begin{array}{l}150 \angle 70 \\
\mathrm{~L}\end{array}$ \\
\hline 14 & 13 & $\begin{array}{l}\text { Рудник «Центральный» (средняя } \\
\text { часть, север) }\end{array}$ & $57 \angle 15$ & $182 \angle 64$ & $321 \angle 20$ & $\begin{array}{l}188 \angle 63 \\
\mathrm{p}\end{array}$ & $\begin{array}{l}98 \angle 86 \\
\text { ls }\end{array}$ \\
\hline \multirow[t]{2}{*}{15} & 13a & $\begin{array}{l}\text { Рудник «Центральный» (средняя } \\
\text { часть, юг) }\end{array}$ & $91 \angle 15$ & $354 \angle 14$ & $239 \angle 60$ & $\begin{array}{l}80 \angle 70 \\
\text { ps }\end{array}$ & $\begin{array}{l}296 \angle 23 \\
\text { ls }\end{array}$ \\
\hline & & Региональное поле напряжений & $356 \angle 60$ & $254 \angle 8$ & $159 \angle 30$ & $\begin{array}{l}164 \angle 74 \\
\text { pw }\end{array}$ & $\begin{array}{l}314 \angle 17 \\
\mathrm{lw}\end{array}$ \\
\hline
\end{tabular}

П р и м е ч а н и е. Азимут и угол погружения осей главных нормальных напряжений: $\sigma_{1}-$ ось растяжения, $\sigma_{2}-$ промежуточная ось, $\sigma_{3}-$ ось сжатия; $\tau_{\max }$ - азимут и угол падения плоскости действия максимальных касательных напряжений; геолого-кинематические типы: w взброс, s - сброс, l - левый сдвиг, p - правый сдвиг.

$\mathrm{N}$ o t e. Azimuth and dip angle of major normal stresses: $\sigma_{1}-$ extension axis; $\sigma_{2}-$ transition axis; $\sigma_{3}-$ compression axis; $\tau_{\max }-$ azimuth and dip angle of the plane of maximum tangential stresses; kinematic type: $\mathrm{w}$ - reserve fault; $\mathrm{s}$ - normal fault, $\mathrm{l}$ - sinistral strike-slip fault; $\mathrm{p}$ - dextral strikeslip fault.

становленном кинематическим методом.

Тектонофизические исследования на месторождении Расвумчорр (рудник «Центральный») проводились в его южной части на горизонтах +835 и +745 южного борта карьера в разных крыльях зоны субширотного разлома, оперяющего Главный разлом. Азимутальные характеристики изученного разлома (оперяющего по отношению к Главному разлому) варьируются от аз. пад. $19^{\circ} \angle 35^{\circ}$ на верхних уступах до $344^{\circ} \angle 35-40^{\circ}$ на нижнем, а его кинематический тип по бороздам скольжения определен как правый взбросо-сдвиг. Тип Главного разлома по геолого-структурным данным устанавливается как взбросо-надвиг с неоднократной циклической инверсией направления смещения. Всего на руднике выделено три локальных стресс-состояния (табл. 2, т.н. 10, 13 и 13а). Локальные стресс-состояния в висячем (рис. 12, т.н. 10, горизонт +835) и лежачем (т.н. 13, горизонт +745) крыльях характеризуются переиндексацией осей сжатия и растяжения. На рис. 13 показаны полюс разлома $\mathrm{R}$, его плоскость $\mathrm{R}_{1}-\mathrm{R}_{2}$ и вектор перемещения ОА, зафиксированный в карьере на верхнем уступе. Оси локальных стресс-состояний в т.н. 10 и 13 лежат в разных крыльях, видна их переиндексация. При этом они близки к плоскости разлома и стремятся занять положение, параллельное и перпендикулярное вектору перемещения разлома, что хорошо согласуется с данными математического и физического моделирования [Осокина, 1987, 1997] и полевыми исследованиями разломов [Сим, 1980, 1996].

На стереограмму (рис. 13) вынесены оси сжатия и растяжения общего поля напряжений (табл. 2), согласно которому перемещение по разлому должно быть 


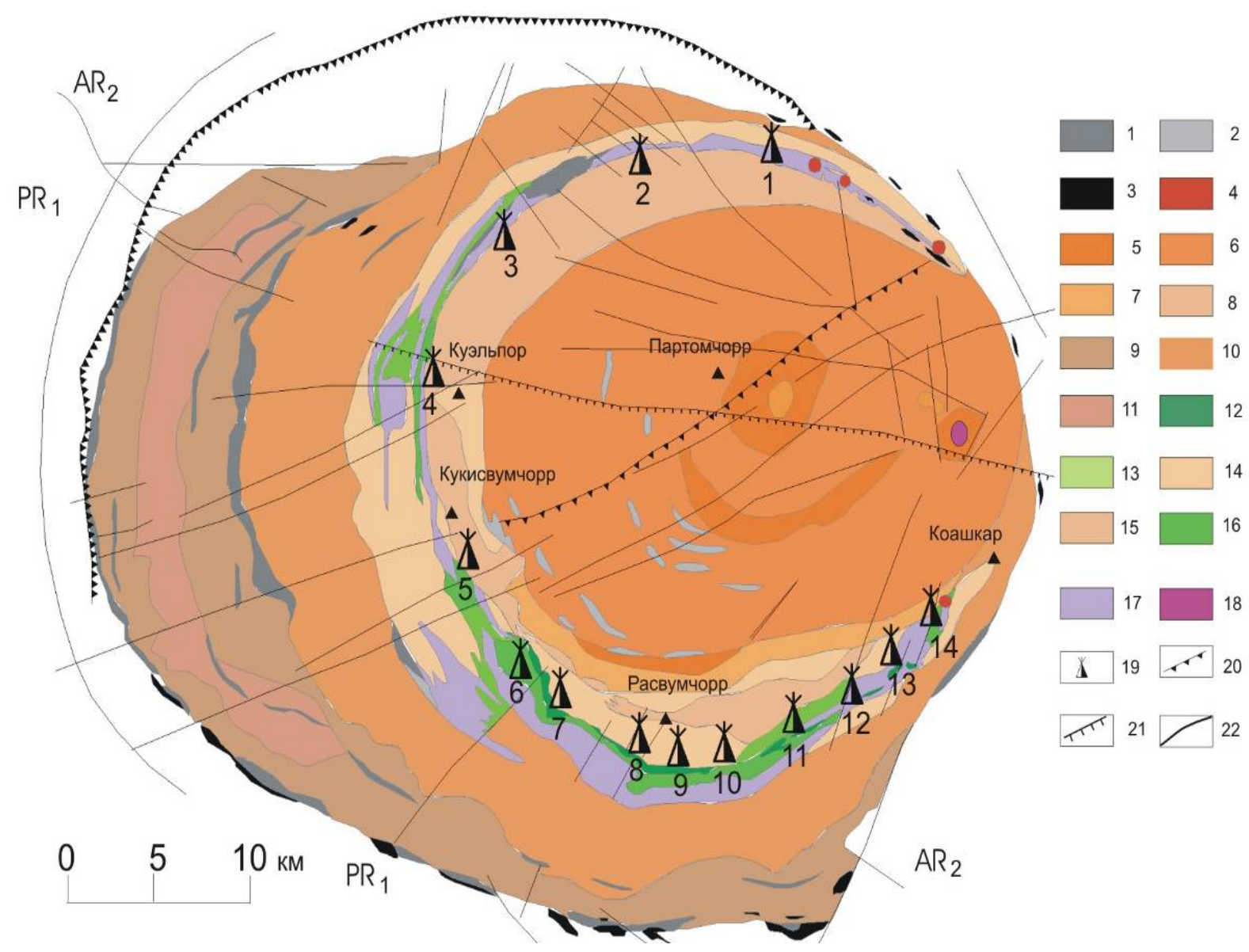

Рис. 11. Геологическая карта Хибинского массива. Составлена В.П. Павловым и др. (по: [Геология...., 2002]). 1 - нефелиновые фениты; 2 - роговики различного состава; 3 - щелочно-ультраосновные породы; 4 - трубки взрыва; 5 - фойяиты массивные; 6 - фойяиты трахитоидные; 7 - щелочные сиениты; 8 - лявочорриты; 9 - хибиниты массивные; 10 - хибиниты трахитоидные; 11 - хибиниты нечетко трахитоидные; 12 - апатит-нефелиновые руды; 13 - ювиты; 14 - рисчорриты массивные; 15 - рисчорриты гнейсовидные; 16 - уртиты массивные; 17 - ийолит-уртиты гнейсовидные; 18 - карбонатиты; 19 - месторождения и рудопроявления апатит-нефелиновых руд (1 Валепахк-Намуайв, 2 - Лявочорр, 3 - Партомчорр, 4 - Куэльпор, 5 - Снежный цирк, 6 - Кукисвумчорр, 7 - Юкспор, 8 - Апатитовый цирк, 9 - Расвумчорр, 10 - Эвеслогчорр, 11 - Коашва, 12 - Вуоннемйок, 13 - Ньоркпахк, 14 - Олений Ручей); 20 - Тульокская зона разломов; 21 - разрывные нарушения, установленные по геофизическим данным и аэрофотоснимкам; 22 - установленные разрывные нарушения (названия рудников с тектонофизическими данными выделены курсивом).

Fig. 11. Geological map of the Khibim block. The map is compiled by V.P. Pavlov et al. based on [Геология...., 2002]. 1 - nepheline fenite; 2 hornblende varying in composition; 3 - alkaline-ultrabasic rocks; 4 - volcanic pipes; 5 - trachytoid foyaites; 7 - alkaline syenites; 8 - lyavorchites; 9 - massive khibinites; 10 - trachytoid khibinites; 11 - indefinite trachytoid khibinites; 12 - apatite-nepheline ores; 13 - yuvites; 14 gneissoid rischorrites; 15 - gneissoid rischorrites; 16 - massive urtites; 17 - gneissoid yolite-urtites; 18 - carbonatites; 19 - deposits and mineral occurrences of apatite-nepheline ores (1- Valepakh-Namuaiv, 2 - Lyavochorr, 3 - Partomchorr, 4 - Kuaelpor, 5 - snow cirque, 6 - Kukisvumchorr, 7 - Yukspor, 8 - apatite cirque, 9 - Rasvumchorr, 10 - Eveslogchorr, 11 - Koashva, 12 - Vuonnemjok, 13 - Njorkpakh, 14 - Deer Brook); 20 - Tuljok fault zone; 21 - faults determined from geophysical data and aerial photos; 22 - determined fractures (names of mining sites with tectonophysical data are shown in italics).

взбросо-сдвигом по линии ОС при одноосном сжатии и по линии ОВ - при одноосном растяжении. Часть плоскости разлома ВС соответствует возможным выходам векторов перемещения по плоскости разлома в найденном общем поле напряжений при разных величинах коэффициента $\mu \sigma$. Вектор ОА находится в створе угла ВОС. Из этого следует два вывода: 1 - зафиксированное смещение по разлому согласуется с общим полем напряжений; 2 - вид напряженного состояния найденного общего поля напряжений близок к трехосному по положению реального векторы смещения примерно на равном расстоянии между векторами ВО и OC.

На руднике «Коашва» выделены три однородно напряженных объема с определением их локальных стресс-состояний: два определения (т.н. 11, 11б) относятся к коренным расвумчорритам, одно (т. 11Q) к четвертичным флювиогляциальным отложениям, 

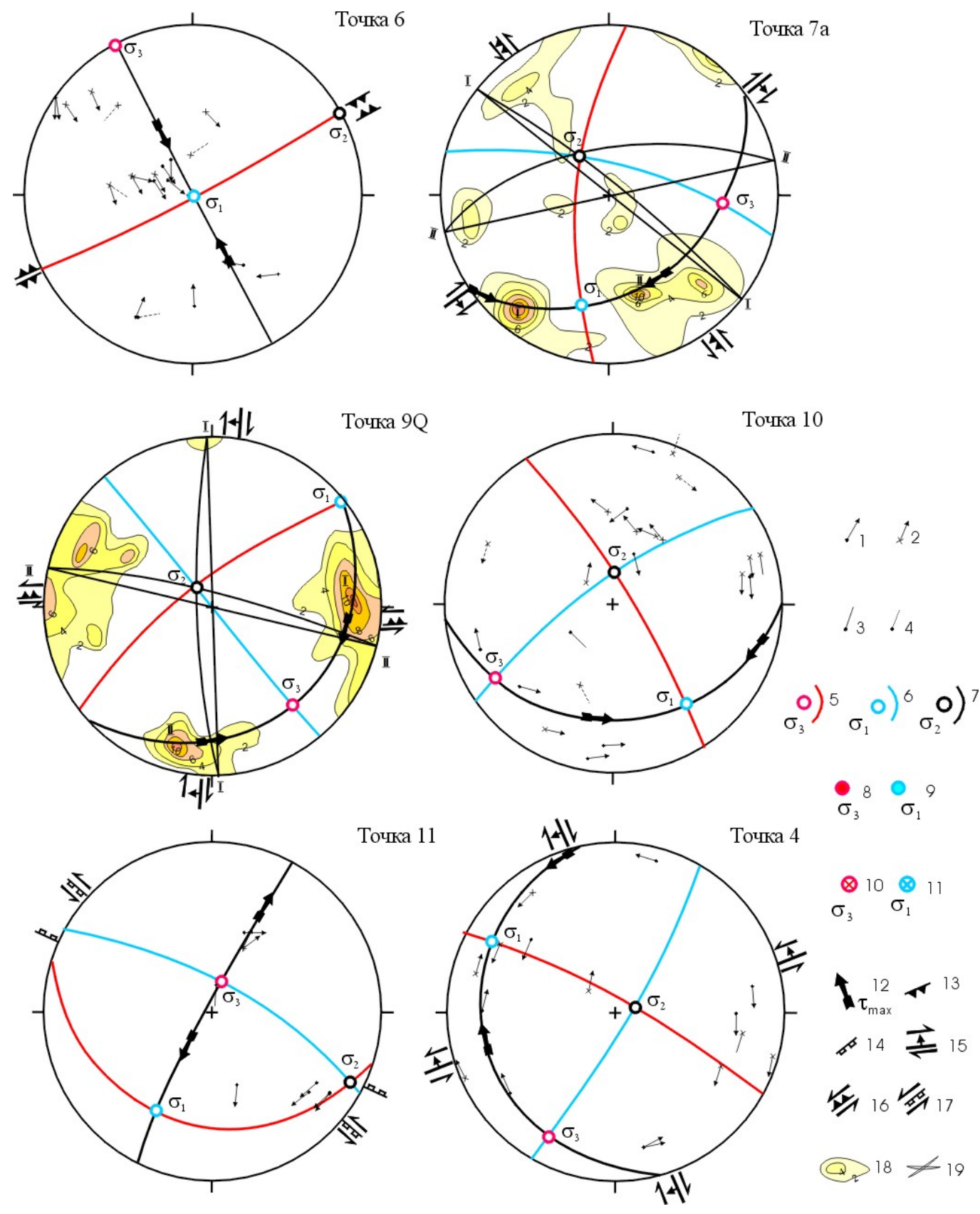

$$
\begin{array}{ccc}
8 & 10 & 11 \\
\sigma_{3} & \sigma_{1}
\end{array}
$$

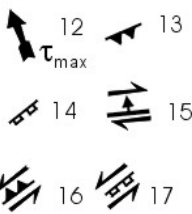

Q $18 \neq 19$

Рис. 12. Стереограммы локальных стресс-состояний Хибинского массива (сетка Вульфа, верхняя полусфера). 1-4 - векторы перемещений на зеркалах скольжения: 1-3 - соответствующие - 1-2 - со знаком смещения, измеренные разными авторами, 3 - без знака смещения, 4 - противоречащие найденному локальному стресс-состоянию; 5-11 - оси главных нормальных напряжений и плоскости их действия: 5-7 - локальных стресс-состояний, восстановленных по измерениям в магматических, 8-9 - в четвертичных породах, 10-11 общего поля напряжений; $\sigma_{1}$ - ось минимальных (растяжения), $\sigma_{2}-$ промежуточных, $\sigma_{3}-$ максимальных (сжатия) сжимающих напряжений; 12 - вектор перемещения по плоскости действия максимальных касательных напряжений в точке полюса; 13-17 - простирания плоскостей действия максимальных касательных напряжений и их кинематические типы: 13 - взбросы, 14 - сбросы, 15 - сдвиги, 16 - взбросо-сдвиги, 17 - сбросо-сдвиги; двойными линиями выделена преобладающая составляющая перемещений, зубцы ориентированы по падению плоскостей; 18 - изолинии плотности трещин; 19 - сопряженные сколовые трещины.

Fig. 12. Stereograms of local states of stresses of the Khibin block. The Wulff net, upper hemisphere. 1-4 - vectors of displacements on slickensides: 1-3 corresponding to the local state of stresses (1-2 - with determined sign if displacement as per measurements by various authors, 3 without displacement sign), 4 - contradicting with the local state of stresses; 5-11 - axes and planes of main normal stresses: 5-7 - local states of stresses determined from measurement in magmatic rocks, 8-9 - in the Quaternary rocks, $10-11$ - general stress field; $\sigma_{1}-$ axis of minimum stresses (extension), $\sigma_{2}$ - transitional stresses, $\sigma_{3}$ - maximum stresses (compression); 12 - vector of displacement on plane of maximum tangential stresses at pole point; 13-17 - strike of planes of maximum tangential stresses and kinematic types of stresses: 13 - reverse faults, 14 - normal faults, 15 - strike-slip faults, 16 - strike-slip faults with reverse component, 17 - strike-slip faults with normal component. Dual lines show dominating components of displacement; «waves» are oriented by strikes of planes; 18 - isolines of density of fractures; 19 - conjugated shear fractures. 


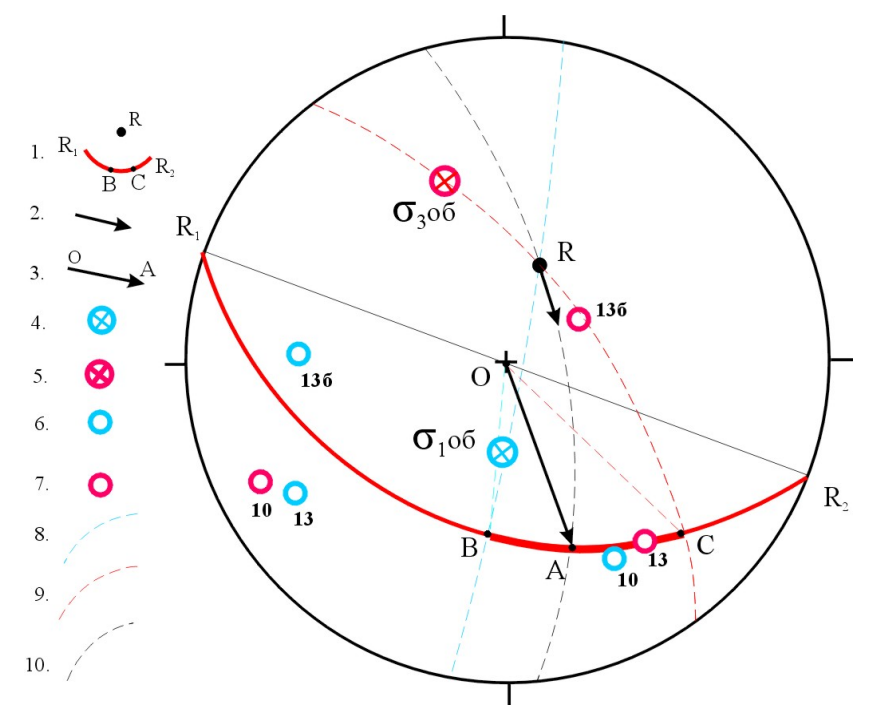

Рис. 13. Стереограмма, иллюстрирующая связь перемещений и осей главных нормальных напряжений вблизи разлома на руднике «Центральный». 1 - полюс $(\mathrm{R})$ и плоскость разлома $\mathrm{R}_{1} \mathrm{R}_{2}$, на которой ВC - интервал возможного выхода векторов перемещений по разлому в общем поле напряжений Хибин при разном виде напряженного состояния («Центральный», горизонты +835 и +745); 2-3 - вектор перемещения по разлому: в точке полюса (2), на плоскости разлома (3); 4-5 - оси минимальных (4) и максимальных (5) сжимающих главных нормальных напряжений общего поля Хибин; 6-7 - оси минимальных (6) и максимальных (7) сжимающих главных нормальных напряжений локальных стресс-состояний; цифрами даны номера точек наблюдений; 8-10 - дуги больших кругов, соединяющих полюс разлома и ось растяжения (8), ось сжатия общего поля (9) и вектор перемещения по разлому (10).

Fig. 13. Stereogram showing the relationship between displacement and axes of main normal stresses near the fault on the Central mining site. 1 - pole (R) and plane of fault $R_{1} R_{2}$, where "BC" is an range of potential outlet of displacement vectors on the fault in the general stress field of the Khibin with various states of stresses (Central, horizons +835 и +745); 2-3 - vector of displacement along the fault: at pole point (2), and on fault plane (3); 4-5 - axes of minimum (4) and maximum (5) compression main normal stresses of the general stress field of the Khibin; 6-7 - axes of minimum (6) and maximum (7) compression main normal stresses of local states of stresses. Numbers show points of measurements; 8-10 - arcs of large circles connecting the fault pole and extension axis (8), compression axis of the general field (9), and vector of displacement along the fault (10).

вскрытым в северо-западном борту карьера. Оси растяжения в т.н. 11 и 11a, разделенных разломом с азимутом падения $130-145^{\circ} \angle 70-80^{\circ}$, субгоризонтальные и субмеридиональные, а оси сжатия круто погружаются на юго-восток, обусловливая сдвиго-сбросовое поле напряжений в исследованной части рудника.

Сдвиговое поле напряжений в т.н. 11Q характеризуется субмеридиональным близгоризонтальным сжатием (рис. 13), которое практически совпадает с осями растяжения, восстановленными в коренных породах, а пологая ось растяжения субширотна. Переиндексация осей главных нормальных напряжений в разнесенных в пространстве точках тектонофизических исследований может свидетельствовать о разном возрасте вос- становленных напряжений. Но так как такая переиндексация обычно характерна для разных крыльев разломов, можно предположительно говорить о связи этого явления с активизацией в молодом поле напряжений краевого разлома, в разных крыльях которого расположены т.н. 11 и $11 \mathrm{Q}$.

Трасса Мурманск - Санкт-Петербург. В архейских гранитогнейсах (кольско-беломорский нестратифицированный комплекс [Геологическая карта..., 2001]) Мурманского блока реконструкция тектонических напряжений была произведена в карьере на западной окраине г. Мурманска (см. рис. 12, т.н. 4). В западной стенке карьера выделяется зона небольшого крутопадающего разлома с аз. пад. $205^{\circ} \angle 85^{\circ}$. Ширина зоны дробления составляет 80-90 см, породы в ней обохрены и обводнены. В разных крыльях разлома измерения борозд скольжения произведены разными исследователями. На рис. 12 (т.н. 4) замеры измерения в северном и южном крыльях, произведенные разными исследователями, выделены в точках полюсов трещин отличающимися значками (стрелки с крестиком или с кругом). Все векторы перемещений идеально соответствуют сдвиговому полю напряжений с субгоризонтальными осями ССВ сжатия и ЗСЗ растяжения. Это свидетельствует об отсутствии новейшей активизации разлома.

Другая реконструкция осуществлена по измерениям борозд скольжения в лопийских эндербитах [Геологическая карта..., 2001]), вскрытых в восточном борту трассы Мурманск-Санкт-Петербург между пос. Пулозеро и г. Оленегорск (т.н. 5, табл. 2). Локальное стресссостояние характеризуется взбросовым полем с крутой осью растяжения и осью сжатия, полого погружающейся на северо-запад.

\section{6. ОБЩЕЕ ПОЛЕ НАПРЯЖЕНИЙ}

Все полученные оси сжатия и растяжения локального уровня были вынесены на одну стереограмму (рис. 14), на которой виден значительный разброс в их ориентировках. Заметим, что в анализе участвуют стресс-состояния, восстановленные в породах архейского, девонского и четвертичного возраста. Тем не менее находится такое положение конусов сжатия и растяжения с телесным углом при вершине $45^{\circ}$ и взаимно перпендикулярными осями, в которое не попадают противоположные локальные оси: в конусе растяжения нет осей сжатия и, наоборот, в конусе сжатия нет осей растяжения. Это свидетельствует, согласно основным принципам метода нахождения общего поля напряжений [Cuм, 1980, 1996], о едином поле напряжений, в котором деформируются породы Хибин в неотектонический этап. Распространять это поле на весь Кольский п-ов представляется некорректным, хотя в его реконструкции и участвуют определения локальных стресс-состояний за пределами Хибин (из-за 


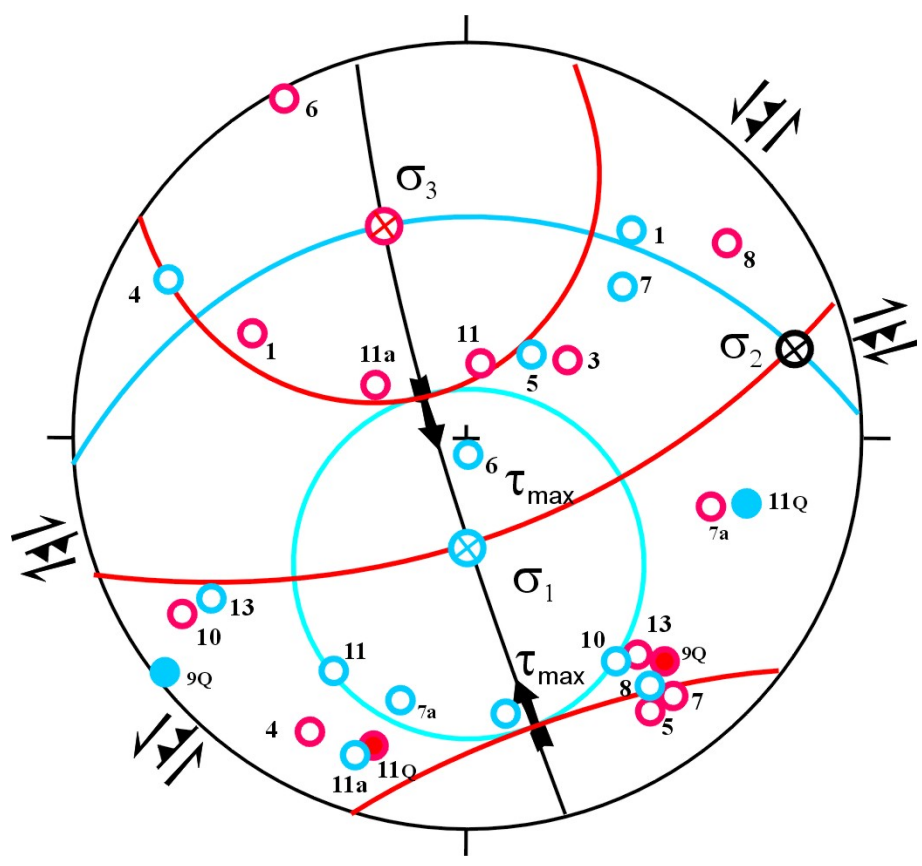

Рис. 14. Стереограмма общего поля напряжений Хибинского массива. Условные обозначения приведены на рис. 11.

Fig. 14. Stereogram of the general stress field of the Khibin block. Legend same as in Figure 11.

малого числа последних). Пологая ось сжатия ССЗ простирания погружается на ЮЮВ по азимуту $159^{\circ} \angle 30^{\circ}$, крутая ось растяжения $-356^{\circ} \angle 60^{\circ}$, плоскости действия максимальных касательных напряжений являются взбросами с подчиненной горизонтальной компонентой перемещений, которая на плоскости $164^{\circ} \angle 74^{\circ}$ - правосдвиговая, а на плоскости $314^{\circ} \angle 17^{\circ}-$ левосдвиговая.

Локальные оси главных нормальных напряжений в т.н. 7 (хибиниты рудника «Олений Ручей») и в водноледниковых отложениях т.н. 9Q практически совпадают (см. рис. 13), а оси растяжения в этих точках имеют общее СВ простирание, но в хибинитах она более крутая. В целом принято, что расхождение в ориентации локальных осей напряжений в близлежащих точках наблюдения в разновозрастных породах незначительно. В таком случае в хибинитах восстановлено молодое поле напряжений (см. рис. 11, 13, табл. 2).

Крутое положение оси растяжения, определяющее в целом взбросовый тип общего поля напряжений, более уверенно относится только к Хибинскому массиву, в котором восстановлены 12 из 14 определений локального стресс-состояния. Возраст восстановленных по бороздам скольжения полей напряжений принимается за неотектонический и современный, так как в определении общего поля напряжений участвуют и локальные стресс-состояния в четвертичных породах. Воздымание Хибинского массива в неотектонический этап, сопровождающееся повышенной сейсмичностью и фиксирующееся в современном рельефе, согласуется с найденным общим взбросовым полем напряжений.

Малая концентрация осей сжатия и растяжения в соответствующих конусах свидетельствует о трехосном напряженном состоянии общего поля напряжений, что согласуется с выводом, полученным ранее при анализе полей напряжений и векторы перемещения по разлому на руднике «Центральный» (см. рис. 12).

\section{7. ОБСУЖДЕНИЕ РЕЗУЛЬТАТОВ}

Приведенные результаты тектонофизических исследований позволяют говорить о двух общих полях напряжений на исследованной части Ковдорского массива. Более древнее поле № 1 взбросовое с субгоризонтальной осью сжатия ЗСЗ простирания, более молодое поле № 2 - сдвиговое с тем же сжатием, но с переиндексацией оси растяжения и промежуточной оси. Поле напряжений № 2 хорошо коррелируется с региональным неотектоническим полем напряжений восточной части Балтийского (Фенноскандинавского) щита, установленным ранее [Сим, 1996, 2000; Sim et $a l ., 2010]$. Обрушение в юго-восточном борту карьера обусловлено в основном наличием благоприятно ориентированных плоскостей крупных трещин и, вероятно, возможным незначительным правосдвиговым перемещением с обстановкой локального растяжения на этом участке. Правосдвиговые перемещения также нашли подтверждение в южном борту карьера (150200 м от плоскости обрушения), где задокументирована серия прототектонических трещин и даек карбонатитов с правосдвиговой кинематикой.

Из-за переориентировки минералов на плоскостях сместителей субпараллельно линии перемещения, требующей особых РТ условий, можно предположить, что возраст взбросового поля напряжений синхронен возрасту карбонатитов последней стадии. Для определения этого возраста требуются дополнительные исследования.

В результате полевых тектонофизических исследований на рудниках Хибинского массива выделены 14 однородно нагруженных объемов с определением локальных стресс-состояний. Они характеризуются, так же как и на Ковдоре, существенной изменчивостью ориентировок осей главных нормальных напряжений. Наибольшее число определений относится к руднику «Олений Ручей», на котором локальные стресссостояния восстановлены в коренных породах как по бороздам скольжения, так и по сколовым сопряженным трещинам в хибинитах, а также в четвертичных флювиогляциальных песках. По всем реконструкциям локальных стресс-состояний определено общее поле напряжений взбросового типа.

На карьере рудника «Железный» показана относительная активность крупных разломов, по-разному 
ориентированных к современному полю напряжений. Разлом $\mathrm{R}_{1}$, близкий по положению к одной из плоскостей действия максимальных касательных напряжений последнего поля, наиболее активный.

На устойчивость бортов карьера влияет не только активность разломов, но и наличие крупных ослабленных плоскостей, неблагоприятно ориентированных относительно выработанного в процессе разработки карьера пространства, а также вид напряженного состояния в локальных объемах горных пород. Современная активность разломов на рудниках Хибинского массива фиксируется по резкой смене ориентировок осей локальных напряжений в разных крыльях.

Как известно из теоретического моделирования напряжений, связанных со смещением по разломам, вблизи зон сдвигов ориентировки осей напряжений внешнего поля (собственно, обусловливающего смещение) плавно изменяются по простиранию, достигая предельной переориентации на концах разлома. Во фронтальной части движущегося крыла ориентировка оси сжатия параллельна, а оси растяжения - перпендикулярна плоскости сдвига; в тыльной части противоположного крыла, наоборот, ось растяжения параллельна, а ось сжатия перпендикулярна плоскости сдвига [Осокина, 1987]. Данные о природных напряжениях полностью согласуются с теоретическими на разломе рудника «Центральный» в Хибинах и частично - на разломе (крупной трещине) в зоне обрушения на руднике «Железный». Поскольку перечисленные разломы не выходят за пределы магматических массивов, удалось зафиксировать возмущения локальных напряжений на концах этих разломов. Разлом $\mathrm{R}_{1}$ на руднике «Железный» продолжается по данным дешифрирования за границу карьера, в пределах которого вскрыта предположительно срединная часть разлома. По всей вероятности, разнообразие ориентировок в разных крыльях разлома $\mathrm{R}_{1}$, не согласующееся с теоретическими расчетами, обусловлено их значительно неоднородным геологическим строением. При сопоставлении данных моделирования сдвигов в однородной среде с данными активизации разломов в природных массивах необходимо иметь в виду значительно более сложное строение последних и более длительное развитие, сопровождавшееся, скорее всего, неоднократным обновлением разломов даже в едином для новейшего этапа общем поле напряжений. Косвенно это подтверждается тем, что вдоль сейсмогенных разрывов распределение амплитуд смещений может быть крайне неоднородным [Стром, Никонов, 1999]. В этом случае локальные напряжения могут быть так же неоднородны. Широкий спектр механизмов афтершоков после сильных землетрясений и разброс последних вдоль основного сейсмогенного шва тоже не противоречит «неупорядоченным» локальным напряжениям в крыльях разломов и нахождению по этим локальным стресс-состояниям общего поля. Имеющиеся данные по тектоническим напряжениям дают возможность выделить только два ранга напряжений: локальные напряжения можно отнести ко II рангу, а общие - к I (или «региональному») рангу.

Неотектонический и современный возраст восстановленных по бороздам скольжения в архей-протерозойских породах восточной части Балтийского щита напряжений установлен различными методами. В Центральной Карелии он определен по результатам специальных геохимических исследований. В пределах Кандалакшского залива он установлен в соответствии с новейшей структурой Кандалакшского грабена, ориентированного поперек «региональной» субгоризонтальной оси растяжения. Последнее в сочетании с крутой осью «регионального» сжатия на этом участке исследований целиком согласуется со структурой грабена. Непротиворечивость локальных стресс-состояний, восстановленных в девонских магматических образованиях и голоценовых отложениях в пределах Хибинского массива, также дает основание относить возраст реконструированных полей напряжений к современному и неотектоническому.

На исследованной части Ковдорского массива выделяются четыре этапа деформирования: два более ранних - по структурным признакам, а два последних - по ориентации осей главных нормальных напряжений общих полей. В отличие от Ковдора в Хибинах восстановлено единственное «региональное» поле. Отметим, что взбросовое поле напряжений 3-го этапа деформирования (и 1-е по реконструкции тектонических напряжений) на Ковдорском массиве похоже на взбросовое поле на рудниках Хибинского массива. В обоих массивах ось сжатия субгоризонтальна. Предположительно крутая ось растяжения отражает этап хрупкого деформирования, проявившегося после остывания обеих интрузий на глубине, и последующее их воздымание. Дальнейшая история развития привела массивы к разному современному напряженному состоянию. На неотектоническом и современном этапах механизм их деформирования может определяться двумя источниками субгоризонтального сжатия. Один из них остаточные гравитационные напряжения, сохранившиеся в значительно эродированных магматических телах как «память» о пребывании в стесненных условиях на глубине [Rebetsky, 2008], а второй - возможное влияние процессов спрединга в Северной Атлантике. Современное сдвиговое поле на Ковдоре по ориентации оси сжатия не противоречит его обусловленности процессами раздвижения в Атлантике, хотя не исключает и наличия гравитационных напряжений. Хибинский массив, имеющий форму лополита, под воздействием горизонтального сжатия любого генезиса должен выдавливаться вверх, что фиксируется субвертикальной осью растяжения «регионального» поля Хибин и подтверждается современным рельефом - наиболее высокие вершины Кольского п-ова находятся именно на этом массиве, он продолжает «всплывать». 


\section{8. Выводы}

Проведенные на рудниках Кольского п-ова тектонофизические исследования дали возможность сделать несколько выводов, имеющих теоретическое и практическое значение. Получены данные о современном напряженном состоянии, которое играет значительную роль в устойчивости горных выработок. На обоих массивах установлены «региональные» субгоризонтальные оси сжатия. При этом деформирование двух исследованных массивов на новейшем и современном этапах происходит по-разному: Ковдорский массив деформируется в сдвиговом поле напряжений с субгоризонтальной запад-северо-западной ориентацией оси сжатия, не противоречащей влиянию рифтогенеза в Северной Атлантике, а Хибинский массив, имеющий лополитообразную форму, независимо от генезиса горизонтального сжатия, выдавливается наверх. Расчеты Ю.Л. Ребецкого величин остаточных гравитационных горизонтальных напряжений в Хибинах с использованием результатов полевых тектонофизических исследований, приведенных в данной работе, показали, что они хорошо коррелируются с данными инструментальных измерений напряжений в этом массиве и что роль дальнодействующих источников горизонтальных напряжений здесь практически исключена [Ребецкий и дp., 2011].

\section{9. БЛАГОДАРНОСТИ}

Авторы выражают благодарность заместителю директора Горного института Кольского научного центра РАН профессору А.А. Козыреву и доценту этого института В.В. Рыбину за помощь в организации полевых работ, а также заведующему лаборатории тектонофизики ИФЗ РАН Ю.Л. Ребецкому за обсуждение работы на всех стадиях и конструктивные замечания.

Работа выполнена при поддержке грантов РФФИ 09-05-12064 офи_м, 09-05-00687a, 09-05-1213а, 09-0501022a.

\section{0. ЛИТЕРАТУРА}

Бабак В.И., Гарбар Д.И., Сим Л.А., Касаткин Ф.Г. Тектонические условия и тенденции развития Онежского озера // Изв. ВУЗов. Геология и разведка. 1979. № 2. С. 44-51.

Бабак В.И., Николаев Н.И. Пояснительная записка к карте геоморфолого-неотектонического районирования Нечерноземной зоны РСФСР (за исключением горной части Урала и Калининградской области). М-б 1:500000. М.: МГУ, 1983.

Бабак В.И., Сим Л.А., Касаткин Ф.Г. Вариации тектонического поля напряжений восточной части Балтийского щита // Бюл. МОИП. Отд. геол. 1981. Т. 56, вып. 1. С. 150.

Геологическая карта Кольского региона. М-б 1:100000 / Ред. Ф.П. Митрофанов. Апатиты, 2001.

Геология рудных районов Мурманской области / В.И. Пожиленко, Б.В. Гавриленко, Д.В. Жиров, С.В. Жабин. Апатиты: КНЦ PAH, 2002. 359 c.
Гзовский М.В. Тектонические поля напряжений // Известия АН СССР. Серия геофизическая. 1954. № 5. С. 390-410.

Гзовский М.В. Основы тектонофизики. М.: Наука, 1975. 375 с.

Гущенко О.И. Анализ ориентировок сколовых тектонических смещений и их тектонофизическая интерпретация при реконструкции палеонапряжений // Доклады АН СССР. 1973. Т. 210, № 2. C. 331-334.

Гущенко О.И. Метод кинематического анализа структур разрушения при реконструкции полей тектонических напряжений // Поля напряжений в литосфере. М.: Наука, 1979. С. 7-25.

Гущенко О.И., Сим Л.А. Обоснование метода реконструкции напряженного состояния земной коры по ориентировкам сдвиговых тектонических смещений (по геологическим и сейсмологическим данным) // Механика литосферы: Тез. докл. Всесоюз. науч.-техн. совещ. Л.-М., 1974. С. 5-8.

Данилович В.Н. Метод поясов в исследовании трещиноватости, связанной с разрывными смещениями. Иркутск: Иркут. политехн. ин-т, 1961. 47 с.

Жиров Д.В., Сим Л.А. Мультикинематические дизъюнктивы как регуляторы транспозициональных полей напряжений на примере массива пород Ковдорского апатит-магнетитового месторождения // Триггерные эффекты в геосистемах: Тез. докл. семинара-сов. (Москва, июнь 2010). М.: ИДГ РАН, 2010. С. 3132.

Карта новейшей тектоники СССР и сопредельных областей м-ба 1:1000000 / Ред. Н.И. Николаев. М.: ГУГК СМ, 1985.

Кольская сверхглубокая. М.: Недра, 1984. 490 с.

Кошечкин Б.И. Голоценовая тектоника восточной части Балтийского щита. Л.: Недра, 1979. 152 с.

Митрофанов Ф.П., Баянова Т.Б., Балабонин Н.Л., Сорохтин Н.О., Пожиленко В.И. Кольский глубинный раннедокембрийский коллизион: новые данные по геологии, геохронологии, геодинамике и металлогении // Вестник СПбГУ. 1997. Сер. 7, вып. 3. C. 5-18.

Мультимедийный справочник по минерально-сырьевым ресурсам и горно-промышленному комплексу Мурманской области: Цифровой информационный ресурс / Под ред. Ф.П. Митрофанова. Апатиты: ГИ КНЦ РАН, 2001. Ч. 1. (CD-ROM).

Николаев П.Н. Методика тектонодинамического анализа. М.: Недра, 1992. 295 с.

Осокина Д.Н. Об иерархических свойствах тектонического поля напряжений и деформаций в земной коре // Поля напряжений и деформаций в земной коре. / Под ред. А.С. Григорьева, Д.Н. Осокиной. М.: Наука, 1987. С. 136-151.

Осокина Д.Н. Парагенезы напряжений и вторичных структур в зонах активных разломов: Математическое моделирование. Структурные парагенезы и их ансамбли / Под ред. А.В. Лукьянова. М.: ГЕОС, 1997. С. 129-131.

Ребецкий Ю.Л., Сим Л.А., Козырев А.А., Рыбин В.В., Жиров Д.В. Первые оценки величин напряжений по геологическим данным // Современное состояние наук о Земле: М-лы междунар. конф., посв. памяти В.Е. Хаина. М.: Геол. факультет МГУ, 2011, С. 1553-1554. http://khain2011.web.ru.

Ронов А.Б., Хаин В.Е., Балуховский А.Н. Атлас литологопалеогеографических карт мира. Мезозой и кайнозой континентов и океанов / Отв. ред. В.Л. Барсуков, Н.П. Лаверов. Л.: ВСЕГЕИ, 1989. 79 с.

Рухлов А.С., Иванников В.В., Белл К. Рекуррентный дайководиатремовый магматизм Кандалакшского грабена (Кольская щелочная провинция) // Рифтогенез, магматизм, металлогения докембрия. Корреляция геологических комплексов Фенноскандии. Тез. междунар. конф. Петрозаводск, 1999. С. 124-125.

Светов А.П., Свириденко Л.П. Магматизм шовных зон Балтийского щита. Л.: Наука. Ленинградское отд., 1991. 197 с.

Сим Л.А. Выявление новейших активизированных разломов в условиях слабообнаженных районов (на примере зоны сочленения Мезенской синеклизы и Среднего Тимана): Автореф. дис. ... канд. геол.-мин. наук. М.: МГУ, 1980. 24 с.

Сим Л.А. Некоторые особенности полей напряжений в зонах разломов (по геологическим и сейсмологическим данным) // Поля 
напряжений и деформаций в земной коре. М.: Наука, 1987. С. 151-158.

Сим Л.А. Изучение тектонических напряжений по геологическим индикаторам (методы, результаты, рекомендации) // Изв. ВУЗов. Геология и разведка. 1991. № 10. С. 3-22.

Сим Л.А. Некоторые особенности взаимосвязи неотектонических движений Восточно-Европейской платформы с глобальным тектогенезом на основе изучения неотектонических напряжений) // Неотектоника и современная геодинамика контин. и океанов: Тез. докл. XX1X тект. сов. М., 1996. С. 132-134.

Сим Л.А. Влияние глобального тектогенеза на новейшее напряженное состояние платформ Европы // М.В. Гзовский и развитие тектонофизики. М.: Наука, 2000. С. 326-350.

Сим Л.А. О возможной причине эрозионного сноса за мезозой кайнозой и в начале новейшего этапа на Фенноскадинавском щите // Свойства, структура, динамика и минерагения литосферы Восточно-Европейской платформы: Материалы XVI международной конференции, 20-24 сентября 2010 г. Воронеж: Научная книга, 2010. С. 216-221.

Сим Л.А., Наумкин А.Н., Никулин В.И., Симонов Д.А. Тектонофизическое изучение разломов Карелии в связи с выбором площадки для строительства Карельской АЭС // Тектонофиз. аспекты разломообразования в литосфере: Тез. Всес. сов. «Разломообразование в литосфере: тектонофиз. аспекты». Иркутск, 1990. C. 63.

Сим Л.А., Попова З.В., Шенкман Е.Я., Гущенко А.О., Серов А.В. Поля напряжений в зонах разломов по геологическим и экспериментальным данным // Эксперим. тект. в решении задач теорет. и практ. геологии: Тез. Второго Всес. симп. в Ялте. Киев, 1987. С. $150-151$.

Сим Л.А., Свириденко Л.П., Брянцева Г.В. Об унаследованном развитии неотектонических разломов восточной части Балтийского щита // Разломообразование и сейсмичность в литосфере: тектонофизические концепции и следствия: М-лы Всерос. сов. (18-21 августа 2009 г.). Т. 1. Иркутск: ИЗК СО РАН, 2009. C. $100-102$.

Строение и динамика литосферы Восточной Европы. Результаты исследований по программе EUROPROBE. - М.: Геокарт: Геос, 2006. 736 с.

Стром А.Л., Никонов А.А. Распределение смещений вдоль сейсмогенных разрывов и учет неравномерности подвижек при палеосейсмологических исследованиях // Вулканология и сейсмология. 1999. № 6. С. 47-59

Шерман С.И. О потенциальной способности глубинных разломов к магмоконтролирующей деятельности // Вестник научной информации Забайкальского отд. Геогр. о-ва СССР. Чита, 1966. № 5. C. 16-24.

Garetsky R.G., R.E. Aizberg R.E., Karabanov A.K., Palienko V.P., Sliaupa A.I. Neotectonics and Neogeodynamics of Central Europe // Geotectonics. V. 33. № 5. P. 343-352.

Rebetsky Yu.L. Possible Mechanism of Horizontal Compression Stress Generation in the Earth's Crust // Doklady Earth Sciences. 2008. V. 423. № 2. P. 1448-1451. doi:10.1134/S1028334X08090274.

Sim L.A., Zhirov D.V., Smaglichenko T.A., Smaglichenko A.V. Results of the neotectonic stress state study in the eastern part of Baltic shield // Geoph. Research Abstr. V. 12, EGU2010-3599, 2010, EGU General Assembly 2010.

Zoback M.L., Zoback M.D., Adams J., Assumpção M., Bell S., Bergman E.A., Blümling P., Brereton N.R., Denham D., Ding J., Fuchs K., Gay N., Gregersen S., Gupta H.K., Gvishiani A., Jacob K., Klein R., Knoll P., Magee M., Mercier J.L., Müller B.C., Paquin C., Rajenran K., Stephansson O., Suarez G., Suter M., Udias A., Xu Z.H. \& Zhizhin M. Global patterns of tectonic stress // Nature. 1989. V. 341. № 6240. P. 291-298. doi:10.1038/341291a0.

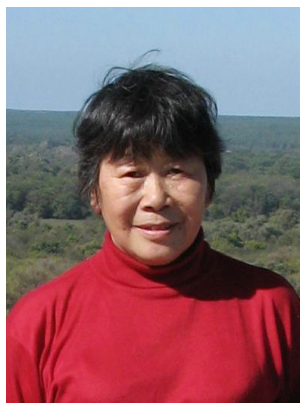

Сим Лидия Андреевна, докт. геол.-мин. наук, в.н.с.

Институт физики Земли им. О.Ю. Шмидта РАН

123995, Москва, ул. Большая Грузинская, 10, стр. 1, Россия

\e-mail: sim@ifz.ru

Sim, Lidia A., Doctor of Geology and Mineralogy, Lead Researcher

The Schmidt Institute of Physics of the Earth RAS

123995, Moscow, Bolshaya Gruzinskaya street, 10-1, Russia

$\triangle$ e-mail: sim@ifz.ru

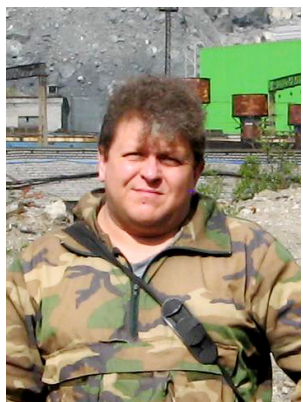

Жиров Дмитрий Вадимович, зав. отделом

Геологический институт Кольского научного центра РАН

184209, Мурманская обл., Апатиты, ул. Ферсмана, д. 14, Россия

e-mail: zhirov@geoksc.apatity.ru

Zhirov, Dmitry V., Head of Section

Geological Institute The Kola Science Centre RAS

184209, Apatity, Fersman street, 14, Russia

e-mail: zhirov@geoksc.apatity.ru 
Маринин Антон Витальевич, канд. геол.-мин. наук., с.н.с.. Институт физики Земли им. О.Ю. Шмидта РАН

123995, Москва, Большая Грузинская ул., 10, стр. 1, Россия

e-mail: marinin@yandex.ru

Marinin, Anton V., Candidate of Geology and Mineralogy, Senior Researcher The Schmidt Institute of Physics of the Earth RAS

123995, Moscow, Bolshaya Gruzinskaya street, 10-1, Russia

e-mail: marinin@yandex.ru 